\title{
Urodimento
}

REVISTA DE ESTUDOS EM ARTES CÊNICAS

E-ISSN 2358.6958

\section{0 anos de Black or White: discussões interculturais através das alasa kanyas da dança indiana Odissi no videoclipe de Michael Jackson}

\author{
Andrea Itacarambi Albergaria \\ Mariana Baruco Machado Andraus
}

Para citar este artigo:

ALBERGARIA, Andrea Itacarambi; ANDRAUS, Mariana Baruco Machado. 30 anos de Black or White: discussões interculturais através das alasa kanyas da dança indiana Odissi no videoclipe de Michael Jackson. Urdimento - Revista de Estudos em Artes Cênicas, Florianópolis, v. 2, n. 41, set. 2021.

do) DOI: http:/dx.doi.org/10.5965/1414573102412021e0201

Este artigo passou pelo Plagiarism Detection Software| iThenticate 
30 anos de Black or White: discussões interculturais através das alasa kanyas da dança indiana Odissi no videoclipe de Michael Jackson

\author{
Andrea Itacarambi Albergaria ${ }^{1}$ \\ Mariana Baruco Machado Andraus²
}

\title{
Resumo
}

Neste artigo propomos refletir sobre o tema da interculturalidade prenunciado no videoclipe Black or White, de Michael Jackson, em 1991, colocando-o em perspectiva com discussões interculturais no contexto das artes da cena na atualidade. Apesar do formato de "revista" adotado pelo videoclipe, em suas sucessivas cenas de danças de diferentes culturas, notamos que as escolhas referentes à dança Odissi têm, todas elas, propósitos bem definidos e interlocução com a letra da música, cabendo, portanto, uma análise dessas escolhas, especialmente das alasa kanyas. Esta percepção nos leva a argumentar a favor do pioneirismo do videoclipe que, na década de 1990, prenunciou o debate sobre interculturalidade, movimento das artes cênicas que se amplia a partir dos anos 1970, e equidade atualmente em pauta em esfera social mais ampla, bem como possíveis diferenças de leituras entre gerações.

Palavras-chave: Odissi. Interculturalidade. Cultura Pop. Intergeracionalidade.

30 years of Black or White: intercultural discussions through the alasa kanyas of the Indian dance Odissi in the music video of Michael Jackson

\begin{abstract}
In this article we propose to reflect on the theme of interculturality foreshadowed in the music video Black or White, by Michael Jackson, in 1991, putting it in perspective with intercultural discussions in the context of the scene arts today. Despite the "magazine" format adopted by the video clip, in its successive dance scenes from different cultures, we note that the choices related to Odissi dance all have well-defined purposes and interlocution with the lyrics of the song, therefore, justifying a detailed analysis of these choices, especially of the alasa kanyas. This perception leads us to argue in favor of the pioneering spirit of this music video that, in the 1990s, foreshadowed the debate on interculturality, movement of the performing arts that expanded from the 1970s onwards, and equity currently on agenda in the broader social sphere, as well as possible differences in readings between generations.
\end{abstract}

Keywords: Odissi. Interculturality. Pop Culture. Intergenerationality.

1 Doutoranda em Artes da Cena - Universidade Estadual de Campinas (UNICAMP). Mestre pelo mesmo curso e mesma Universidade. Professora autônoma. andreaodissi@gmail.com

(9) http://lattes.cnpq.br/7133431315853412 (iD https://orcid.org/0000-0001-6964-2237

2 Pós-doutorado na Pontifícia Universidade Católica de Campinas (2014). Doutorado em Artes da Cena, Instituto de Artes, Universidade Estadual de Campinas (UNICAMP, 2012). Mestrado no mesmo curso e universidade (2004). Graduação em Dança, idem (1999). Professora Doutora do Instituto de Artes Graduação em Dança e Pós-Graduação em Artes da Cena, UNICAMP. mandraus@unicamp.br

(9) http://lattes.cnpq.br/0571138942092685 $\quad$ (iD) https://orcid.org/0000-0003-4460-8555 
30 años de Black or White: discusiones interculturales a través de las alasa kanyas de la danza India Odissi en el video musical de Michael Jackson

\section{Resumen}

En este artículo nos proponemos reflexionar sobre el tema de la interculturalidad prefigurado en el video musical Black or White, de Michael Jackson, en 1991, poniéndolo en perspectiva con discusiones interculturales en el contexto de las artes escénicas de hoy. A pesar del formato de "revista" adoptado por el videoclip, en sus sucesivas escenas de danza de diferentes culturas, notamos que las opciones relacionadas con la danza Odissi tienen, todas ellas, finalidades bien definidas e interlocución con la letra de la canción, por lo tanto, depende de un análisis estas opciones, especialmente las alasa kanyas. Esta percepción nos lleva a argumentar a favor del video musical pionero que, en la década de 1990, presagió el debate sobre la interculturalidad, movimiento de las artes escénicas que se expandió a partir de la década de 1970, y la equidad actualmente en la agenda en el ámbito social más amplio, así como las posibles diferencias en las lecturas entre generaciones.

Palabras clave: Odissi. Interculturalidad. Cultura Pop. Intergeneracionalidad. 
Neste artigo propomos refletir sobre o tema da interculturalidade prenunciado no videoclipe Black or White, de Michael Jackson, lançado em 1991, colocando-o em perspectiva com discussões interculturais no contexto das artes da cena na atualidade, à luz do pensamento dos autores Edward Said (2007), Richard Schechner (1984) e Rustom Bharucha (2017). Black or White foi, certamente, um videoclipe marcante para uma geração de brasileiros que tinha acesso a canais de televisão aberta e, em caráter mais excepcional, a canais de televisão a cabo, um acesso que pode ser considerado extremamente restritivo se comparado àquele de que usufruem os jovens hoje, que podem encontrar na internet as danças e manifestações culturais de quaisquer partes do planeta e assistir aos vídeos nos momentos em que thes for oportuno.

É fato que o simples acesso a conteúdos pela internet não promove inputs de caráter formativo: um jovem que assista hoje a esse videoclipe terá ideia de que danças são aquelas? Alguns possivelmente sim, outros provavelmente não. O olhar poderá ser cooptado pela lente dos estereótipos: "indígenas", "asiáticos", "africanos", apresentados no clipe com figurinos e maquiagens "típicos", levando a crer que o "Rei do Pop" teria feito uma absorção superficial de elementos estereotipados dessas culturas. E, de fato, não é impossível que alguns desses elementos não tenham tanto aprofundamento quanto outros. Neste artigo nos debruçamos especificamente sobre o trecho em que a bailarina Yamuna Sangarasivam dança um excerto da coreografia Batu, do estilo tradicional de dança Odissi. Nesse trecho do videoclipe identificamos a possibilidade de aprofundar o tema das alasaskanya, esculturas de figuras femininas presentes em inúmeros templos na Índia.

A dança Odissi, uma das oito danças consideradas clássicas na Índia, é originária do estado de Odisha, costa leste indiana, e teve sua revitalização nos anos 1950, à época da independência do país. Baseada em posturas geométricas, conforme as quais quadrados e triângulos se alternam em movimentação, o estilo Odissi tem em comum com outras formas clássicas - como Bharata Natyam, Kathak, Manipuri, Kuchipudi, Mohiniattam, Kathakali, Sattrya - os gestos (mudras), referências presentes no tratado Natya Shastra, com autoria atribuída ao sábio 
Bharata, entre os séculos II a.C e II. d.C, que demonstram a ligação com o ritual e evidências arqueológicas que caracterizam sua existência ao longo dos séculos. Das danças indianas clássicas, o estilo Odissi tem como característica determinante o estilo lasya, ou feminino, em contraste com o estilo tandava, ou masculino, o que confere à modalidade graciosidade e delicadeza de movimentos, desde giros de pulsos a oblíquos olhares, formando, em ângulos, linhas corporais conhecidas como tribhanga (ou três ângulos corporais), que criam uma sinuosidade presente também no estilo de pintura pattachitra e esculturas da região, cuja arqueologia demonstra existência em achados do século II a.C, na região de Udaygiri, sede do império Kalinga. ${ }^{3}$

Yamuna ${ }^{4}$ aprendeu a dançar Odissi com o mestre indiano Gangadhar Pradhan (1948-2010), conhecido por sua abertura a diálogos, não somente intraculturais, entre as diversas manifestações artísticas da Índia, nas apresentações e cursos sob sua direção em Konark Natya Mandap, Odisha, mas também interculturais, antecipando a abertura, na Índia, da presença de artistas estrangeiros, em seu internacionalmente conhecido Konark Festival. Além da formação artística em Odissi, Bharata Natyam (dança do sul da Índia) e piano, Yamuna, como ela mesmo se define - uma pessoa transnacional, imigrante nos Estados Unidos multicultural - esteve sempre atenta às questões do ser humano e suas relações sociais. À época de sua participação no videoclipe, Yamuna, estudante de mestrado em Antropologia da Dança na Universidade da Califórnia, em Los Angeles, controlou sua emoção ao receber a notícia de sua aprovação para dançar Odissi ao lado de Michael Jackson e atualmente, após três décadas do acontecimento, a antropóloga também é conhecida pela sua atuação e coordenação no grupo de estudos da mulher e gênero na Universidade de Nazareth, onde recebeu o prêmio LGBTQ+ Education and Advocacy Award 2018, pela sua constante luta por políticas de resistência e do seu compromisso com a diversidade.

${ }^{3}$ A dança Odissi como forma artística proveniente do estado de Odisha, antiga região de Kalinga encontra-se disponível em https://en.wikipedia.org/wiki/Odissi, site oficial do governo indiano. Acesso em: 01 set. 2020.

Yamuna Sangarashivam, indiana de Tâmil Nadu, cresceu no Sri Lanka e é residente nos Estados Unidos desde a juventude. Atualmente é professora doutora em Antropologia na Universidade Nazareth College, nos Estados Unidos. Sua biografia está disponível em https://www2.naz.edu/dept/sociologyanthropology/faculty-and-staff/yamuna-sangarasivam. Acesso em: 28 ago. 2020 
A antropologia, principalmente, é o estudo de múltiplas e diversas formas culturais de ser e de saber, diz Sangarasivam. Conforme a tecnologia avança e o mundo se torna mais conectado globalmente, é impossível prever como serão os empregos de amanhã. "O que sabemos", diz ela, "é que pessoas de diferentes países, falando vários idiomas e com identidades transnacionais, trabalharão juntas. Para ter sucesso, é preciso aprender a viver e trabalhar cooperativamente e colaborativamente, e para criar e produzir conhecimento em contextos multiculturais. A antropologia prepara você para fazer exatamente isso". ${ }^{5}$

Consideramos fundamental trazer luz para esta mulher, bailarina, de origem indiana, e a força que seu trabalho trouxe ao videoclipe do astro pop. Conforme elaboraremos adiante, embora Michael Jackson "passe" por várias danças, é com Yamuna que se desenvolve um dueto que consiste em um diálogo que pode ser considerado mais aprofundado, especialmente quando se conhece as razões das escolhas das posturas e expressividades da dança indiana. Diz Agamben (2009, p. 65):

Perceber no escuro do presente essa luz que procura nos alcançar e não pode fazê-lo, isso significa ser contemporâneo. Por isso os contemporâneos são raros. E por isso ser contemporâneo é, antes de tudo, uma questão de coragem: porque significa ser capaz não apenas de manter fixo o olhar no escuro da época, mas também de perceber nesse escuro uma luz que, dirigida para nós, distancia-se infinitamente de nós.

Pode-se dizer que o astro pop tenha enxergado as trevas de seu tempo e de tempos futuros e produzido uma obra que, nesse sentido, possa ser conceituada como contemporânea? É possível postular que o que há de contemporâneo no videoclipe, tomando por pressuposto a conceituação de Agamben, seja justamente o esforço de diálogo intercultural que, naquele momento - anos 1990 - já pressionava as paredes dos templos do contemporâneo, causando fissuras que hoje afloram no debate público de forma presente e cotidiana?

Olhando em retrospecto e à luz de tensões políticas e sociais recentes, como

\footnotetext{
5 "Anthropology, principally, is the study of multiple and diverse cultural ways of being and ways of knowing," Sangarasivam says. As technology advances and the world becomes more globally connected, it is impossible to predict what the jobs of tomorrow might look like. "What we do know," she says, "is that people from different countries, speaking multiple languages, and with transnational identities are going to be working closer together. To be successful, one must learn to live and work cooperatively and collaboratively, and to create and produce knowledge in multicultural contexts. Anthropology prepares you to do exactly that." (Tradução nossa). Disponível em: https://www2.naz.edu/dept/sociology-anthropology/faculty-and-staff/yamuna-sangarasivam/ Acesso em: 13 nov. 2020.
} 
o assassinato do jovem negro, George Floyd, em 25 de maio de 2020, em Minneapolis (EUA), estrangulado por um policial branco, bem como inúmeros casos de violência racista em solo brasileiro, pondera-se, afinal, que a preocupação de Michael Jackson com a questão racial e interétnica talvez fosse mais profunda e relevante do que a linguagem consumista de videoclipes dos anos 1990 possibilitava entrever. A despeito de algumas imagens estereotipadas no videoclipe, no caso da dança indiana Odissi houve rigor e coerência com relação à dança original. As danças mais estereotipadas no videoclipe são, especialmente, as africanas e ameríndias, justamente as culturas que passaram por um secular apagamento imposto pelo processo colonizatório nas Américas. E, cumpre registrar, Michael Jackson, como cidadão estadunidense nascido apenas 95 anos após Abraham Lincoln assinar a Emancipation Proclamation ${ }^{6}$, não tinha obrigação de perceber de forma plenamente consciente esse processo de apagamento em sua complexidade?. Essa tarefa é nossa.

Identificamos as escolhas feitas pela bailarina Yamuna Sangarashivam nos trechos do videoclipe relacionados à dança Odissi, e procuraremos relatar, neste artigo, essas escolhas de forma minuciosa. Antes, no entanto, faremos uma descrição geral do videoclipe a partir de uma perspectiva de discussão intercultural.

\section{Black or White cena a cena}

Em 1991 o cantor Michael Jackson (1958-2009) anunciou uma audição para a escolha de bailarinos de danças "étnicas", com o objetivo de compor cenas para a

\footnotetext{
${ }^{6}$ Ato de emancipação assinado em 1o de janeiro de 1863 (Kleff, 2021).
}

Michael Jackson nasceu em 1958 e, nos anos 1970, momento em que o debate sobre a escravidão ressurge no cenário estadunidense, era um adolescente já com a carreira em ascendência no campo da música. Angela Davis contextualiza academicamente o ressurgimento do debate sobre escravidão justamente neste período: "Durante os anos 1970, o debate sobre a escravidão ressurgiu com vigor renovado. Eugene Genovese publicou A terra prometida. Também foram editados The Slave Community [A comunidade escrava], de John Blassingame, o mal concebido Time oh the Cross [Tempo crucificado], de Robert Fogel e Stanley Engerman, e o monumental The Black Family in Slaverya and Freedom [A família negra na escravidão e na liberdade], de Herbert Gutman. Em reação ao ressurgimento desse debate, Stanley Elkins decidiu que era hora de publicar uma edição ampliada de seu estudo Slavery [Escravidão], de 1959” (Davis, 2016, p. 16). Além de Angela Davis, muitos outros autores discutem o apagamento das culturas negras nas Américas; citamos especialmente Franz Fanon (2020) e Reinaldo Rabaka (2013), para ficar em três dos mais expoentes autores que vêm debatendo racismo na contemporaneidade. A literatura é vasta. 
filmagem de um videoclipe prestes a ser lançado. Logo em seguida, com o filme já pronto, lançou a música Black or White ${ }^{8}$ do álbum Dangerous, e o vídeo mostrava o mundo, representado por um globo terrestre, girando no universo e suas pluralidades étnicas e culturais, reveladas por diferentes danças, por meio das quais o astro pop dividia a cena em movimentos vigorosos, com grupos diversos. O videoclipe inicia com um menino de aproximadamente 10 a 12 anos de idade, interpretado por Macaulay Culkin, ouvindo rock em sua casa e levando uma bronca de seu pai devido ao barulho alto em horário inapropriado. Já nesta cena é apresentado o contexto de uma família estadunidense tradicional que não aceita o rock, gênero musical ainda hoje considerado subversivo por pessoas de perfil conservador. O pai bate à porta do quarto e um quadro de Michael Jackson cai no chão, tendo sua moldura de vidro estilhaçada. Neste momento fica claro que o menino branco de classe média tem no cantor negro um ídolo, e o pai tenta "quebrar" essa admiração. O menino, revoltado, toca um acorde em sua guitarra em volume muito alto, que faz com que a poltrona de seu pai seja ejetada e ele vá parar em África. Não sabemos qual a interpretação pretendida pelo artista, mas uma interpretação possível é de que, somente à força, o pai (autoridade) se colocaria diante de culturas por ele consideradas "inferiores". Neste momento inicia-se a música.

Antes de seguir, transcrevemos e traduzimos a letra completa da música, pois é um elemento fundamental para a leitura intercultural e interétnica aqui pretendida:

I took my baby on a Saturday bang Boy is that girl with you?

Yes we're one and the same Now I believe in miracles And a miracle has happened tonight But, if you're thinkin' about my baby It don't matter if you're black or white They print my message in the Saturday Sun I had to tell them I ain't second to none And I told about equality and it's true Either you're wrong or you're right
Eu levei minha garota em uma festa no sábado Rapaz, aquela garota está com você?

Sim somos um e o mesmo Agora, eu acredito em milagres E um milagre aconteceu esta noite Mas, se você está pensando na minha garota Não importa se você é preto ou branco Eles imprimem minha mensagem no Saturday Sun

Eu tive que dizer a eles que não sou incomparável E eu falei a eles sobre igualdade E é verdade, ou você está errado ou está certo

${ }^{8}$ Black or White foi o maior single de Jackson, na América, desde "Billie Jean". Ela ficou no \#1 da Billboard Hot 100 por sete semanas e se tornou o rock single mais vendido dos anos noventa. https://mjbeats.com.br/ahist\%C3\%B3ria-de-black-or-white-87040a20a469 Acesso em: 30 ago. 2020. 
But, if you're thinkin' about my baby It don't matter if you're black or white I am tired of this devil I am tired of this stuff I am tired of this business Sew when the going gets rough I ain't scared of your brother I ain't scared of no sheets I ain't scared of nobody Girl, when the going gets mean Protection

For gangs, clubs, and nations

Causing grief in human relations

It's a turf war on a global scale I'd rather hear both sides of the tale See, it's not about races

Just places, faces

Where your blood comes from is where your space is

I've seen the bright get duller

I'm not going to spend my life being a color

Don't tell me you agree with me When I saw you kicking dirt in my eye But, if you're thinking about my baby It don't matter if you're black or white I said, if you're thinking of being my baby It don't matter if you're black or white I said, if you're thinking of being my brother

It don't matter if you're black or white It's black, it's white It's tough for you to get by

It's black, it's white It's tough for you to get by It'sblack, it'swhite
Mas, se você está pensando na minha garota Não importa se você é preto ou branco Estou cansado desse demônio Estou cansado dessas coisas Estou cansado desse negócio Costure quando as coisas ficam difíceis Eu não tenho medo do seu irmão Eu não tenho medo de lençóis Eu não tenho medo de ninguém Garota, quando as coisas ficam ruins Proteção

Para gangues, clubes e nações Causando sofrimento nas relações humanas É uma guerra territorial em escala global Prefiro ouvir os dois lados da história Veja, não se trata de corridas Apenas lugares, rostos De onde vem seu sangue é de onde está seu espaço

Eu vi o brilho ficar mais opaco

Eu não vou passar minha vida sendo uma cor

Não me diga que você concorda comigo Quando eu vi você chutando terra no meu olho Mas, se você está pensando na minha garota Não importa se você é preto ou branco Eu disse, se você está pensando em ser minha garota

Não importa se você é preto ou branco

Eu disse se você está pensando em ser meu irmão

Não importa se você é preto ou branco

É preto é branco

É difícil para você sobreviver

É preto é branco

É difícil para você sobreviver

É preto é branco

A letra afirma várias vezes, e especialmente ao final, que tanto pretos quanto brancos se deparam com dificuldades e que não importa a cor da pele para se estabelecer laços de amor ou de amizade. O verso "Eu não vou passar minha vida sendo uma cor" expressa o processo reducionista pelo qual provavelmente passou, em sua vida, em função da cor de sua pele, agravado pelo vitiligo que levou a uma alteração aparente e o expôs a toda sorte de julgamentos na opinião pública, na época. Fato é que, se a música fez um enorme sucesso no Brasil dos anos 1990, que ainda vivia predominante à luz do mito da democracia racial e via com bons olhos a perspectiva de intercâmbios culturais, talvez no Brasil de 2020 Michael Jackson seria execrado por setores diferentes e até mesmo opostos. Seu 
videoclipe, no fim das contas, parece beber de referências do teatro intercultural dos anos 1970, que, segundo o crítico indiano Bharucha (1953 - ), procurava oferecer o termo "interculturalidade" como alternativa ao termo "internacionalidade", ou à ideia de um trânsito intercultural mais oficializado, típico do momento de abertura de portos para interações econômicas na transição entre o período da guerra fria e início da globalização:

Então, o que era o interculturalismo na década de 1970? Tenha em mente que não havia uma teoria rigorosa em torno do assunto. Em um nível geral, schechner posicionou o interculturalismo contra o internacionalismo, que foi associado com intercâmbios formais e oficiais de cultura através das fronteiras dos Estados-nações mediadas por instituições e órgãos governamentais. Em contraste, o interculturalismo era visto como um espaço "alternativo", livre e aberto, no qual artistas individuais e companhias teatrais - não havia menção de grupos sociais - podiam interagir com "culturas não-ocidentais". Há problemas óbvios na construção deste binário entre "o Ocidente" e o "não-Ocidente". Para mim, não havia reciprocidade nessa relação. O "não-Ocidente" foi reduzido a um repositório de materiais e recursos que poderiam ser transportados, adaptados, reinventados e recontextualizados em produções que foram finalmente produzidas e consumidas na Europa e na América para plateias nessa parte do mundo (Bharucha, 2017, p. 15).

O professor norte-americano Richard Schechner (1934 - ), uma das principais referências em estudos da performance, em seu artigo $A$ reply from Rustom Bharucha, defende, por sua vez, o uso do termo intercultural como possiblidade (necessária) de comunicação entre culturas, ampliando não só a troca de saberes, mas criando espaços para passagem de culturas sufocadas pelos estados nacionalistas que definem o que é a cultura e para quem e por quem ela será vista:

Mais essencialmente, o intercâmbio intercultural exige um professor: alguém que conhece o corpo de atuação da cultura que está sendo traduzida. O tradutor de cultura não é um mero agente, como pode ser um tradutor de palavras, mas um verdadeiro portador de cultura. É isso que se torna tão importante-performar outras culturas. Não apenas lendo, não apenas visitando ou importando-as - mas realmente as fazendo. Para que assim, "eles" e "nós" sejam elididos, ou colocados experiencialmente lado a lado $^{9}$ (Schechner, 1984, p. 247).

${ }^{9}$ Most essentially, intercultural Exchange takes a teacher: someone who knows the body of performance of the culture being translated. The translator of culture is not a mere agent, as a translator of words might be, but in actual culture bearer. This is whay performing other cultures becomes so important. Not just Reading them, not just visiting them, or importing them - but actually doing them. So that "them" and "us" is elided, 
O problema na construção do binário entre "Ocidente" e "não Ocidente" fora trabalhado, antes, por Edward Said (1935-2003), intelectual palestino autor da importante obra Orientalismo: o Oriente como invenção do Ocidente, em que ele desenvolve a tese de que a palavra "Oriente" diz respeito apenas à experiência de outridade que o europeu tem ao entrar em contato com culturas não europeias:

[...] os franceses e os britânicos - e, em menor medida, os alemães, os russos, os espanhóis, os portugueses, os italianos e os suíços - tiveram uma longa tradição do que vou chamar Orientalismo, um modo de abordar o Oriente que tem como fundamento o lugar especial do Oriente na experiência ocidental europeia. O Oriente não é apenas adjacente à Europa; é também o lugar das maiores, mas ricas e mais antigas colônias europeias, a fonte de suas civilizações e línguas, seu rival cultural e uma de suas imagens mais profundas e mais recorrentes do Outro. Além disso, o Oriente ajudou a definir a Europa (ou o Ocidente) com a sua imagem, ideia, personalidade, experiência contrastantes (Said, 2007, p. 27).

Sobre o problema da falta de acesso ao teatro produzido a partir da perspectiva intercultural (termo para o qual, posteriormente, ele propõe uma ressignificação), retornamos a Bharucha:

Olhando a partir das políticas de minha localização, ficou claro para mim que a interculturalidade não apresentava um campo de jogo justo. Tratase mais de uma rua de sentido único. Percebi que havia certos privilégios assumidos pelos interculturalistas euro-americanos que não estavam disponíveis na minha parte do mundo, começando pela liberdade de viajar. Mesmo se se pressupõe, num contexto do Terceiro Mundo, que o dinheiro para viajar e para participar de um projeto intercultural é disponibilizado através de financiamento, a realidade é que a liberdade de viajar é severamente restringida por todos os tipos de legalidades determinadas pelas agências do Estado. Assim, mesmo que o interculturalismo pareça existir independentemente do Estado, é a negociação das leis relativas à imigração e à regulamentação de vistos que nos permitem, em primeiro lugar, atravessar as fronteiras [...] (Bharucha, 2017, p. 16).

A crítica elaborada nos anos 1980 por Bharucha, com a qual concordamos integralmente ao analisar o fenômeno de pesquisadores europeus e/ou estadunidenses que se deslocam ao sul global para “absorver” técnicas e estéticas 
de danças tidas como "exóticas", encontra talvez um ponto de exceção no caso de Michael Jackson, se considerarmos sua história de vida e o contexto em que cresceu e em que se fez artista. Negro, filho mais novo de cinco irmãos, destacouse por seu talento como cantor e como dançarino no grupo The Jackson Five, no qual atuou até 1984; e em 1991, aos 33 anos de idade, já com 27 anos de carreira artística e se dedicando exclusivamente à sua carreira solo, compôs uma música para expressar sua visão sobre ser preto ou branco.

Um ponto a se ponderar é que, se o clipe bebe de fontes interculturais daquele período, não é difícil que um jovem brasileiro de 2020 o leia com certa crítica, especialmente pela ideia de equidade étnico-racial que transparece no videoclipe que, embora colocada pelo artista na forma de crítica e com claro apelo à necessidade de transcendência de conflitos étnicos e/ou raciais, pode ser lida à luz do mito da democracia racial, especialmente por um público que não tenha vivido o contexto cultural, social e político do período inicial da globalização. A leitura que propomos neste artigo passa pela compreensão tanto de Bharucha quanto de Schechner de que, desde que a relação não seja vertical, pode-se pensar e falar em interculturalidade. Por esta razão consideramos pertinente pautar uma discussão sobre este videoclipe em 2020: quando uma obra é analisada fora do contexto histórico em que ela foi criada, não raro as intenções do artista são distorcidas ou, até mesmo, invertidas.

Para uma análise acurada do videoclipe de Michael Jackson, concebido e lançado no espírito dos tempos dos anos 1991, entendemos que é preciso repousar essas lentes sobre uma mesa por alguns instantes. Michael Jackson, de forma rasa ou não, abriu portas para formas de dança às quais o público que tinha acesso aos seus videoclipes não estava acostumado, e depois desse momento decorreu, nas décadas subsequentes, um aumento do interesse de pesquisadores de fora da Índia, no eixo Europa - Estados Unidos - Brasil, por estudar de forma aprofundada, especificamente, as danças indianas (e talvez não as demais que aparecem no videoclipe). A relação pode não ser causal, não é essa necessariamente a forma de relação que propomos. Há que se compreender, no entanto, uma linha do tempo que evidencia o interesse e as razões pelas quais temos hoje, no Brasil, tantos pesquisadores estudando dança indiana, o que faz 
desta dança não mais, no Brasil de 2020, uma arte "exótica", mas um tema relevante para o cenário da pesquisa em dança no Brasil, que compartilha com a Índia um lugar de destaque no Sul global, ainda que com diferenças históricas, culturais e políticas evidentes. A Índia, assim como o Brasil, passou por um processo colonizatório que ensejou grandes interferências no campo artístico. Foram processos colonizatórios distintos que, se colocados em perspectiva um em relação ao outro, podem trazer revelações surpreendentes no que diz respeito à arte, a sincretismos e até mesmo à religiosidade brasileira.

O processo de internacionalização das danças indianas se deu inicialmente por meio da abertura da Índia, na pós-independência tardia, na metade do século XX, como colônia da Inglaterra, numa ânsia do governo em se firmar como uma nação de valores ancestrais perante o mundo moderno, investindo em turnês de diferentes artes indianas por diversos países onde muitos indianos iam trabalhar e estudar. Simultaneamente, a própria diáspora indiana para a Europa e Estados Unidos leva consigo valores inerentes à sua origem, para fixação em locais escolhidos, em processos de instalação recorrentes nos movimentos migratórios. De acordo com o pesquisador e bailarino indiano radicado no Brasil Joachim de Andrade, a partir dos anos 1960 a cultura indiana inicia-se mais acentuadamente no Brasil, através de movimentos filosóficos e prática da yoga, porém, no caso específico da dança indiana, o contato inicia-se nos anos 1980. Alguns artistas indianos estiveram no Brasil nas turnês organizadas pelo governo da Índia pela América do Sul, mas, diferentemente do ocorrido na Europa e Estados Unidos, não quiseram aqui se instalar pela instabilidade econômica brasileira. As principais razões apresentadas pelo autor para o não estabelecimento são a dificuldade com a língua e a grande instabilidade da economia brasileira (Andrade, 2007, p. 42).

De forma diversa, a dança indiana chega então ao Brasil por meio dos próprios artistas brasileiros, na mesma década de 1980, oriundos do teatro e da dança, influenciados pelo movimento intercultural crescente, e que buscam na fonte a metodologia desta expressão artística, indo à Índia para imersões de aprendizado nas diferentes técnicas indianas e difundindo-as na volta ao Brasil, seja por meio de espetáculos ou cursos. Detalhes desse movimento serão apresentados adiante, no tópico Fileiras de mulheres ou Naribhanda - da escultura ao videoclipe. 
A presença das artes indianas em território brasileiro cresce a cada ano e, de forma expansiva, insere-se no ensino específico de dança, tanto em graduação, quanto em formação técnica de cursos de dança, fenômeno que ocorre paralelamente ao ensino informal, em espaços alternativos culturais, ligados à cultura da Índia, como escolas de yoga ou templos com temática hinduísta. Apesar de muito do repertório tradicional da dança Odissi ser replicado, um constante movimento de criação em espetáculos autorais surge com base nas técnicas geométricas, posturais e interpretativas desta dança. Para Joachim de Andrade, nossa cena ainda se encontra numa fase inicial deste processo de instalação artística, no qual artistas brasileiros apenas reproduzem uma fase inicial das artes clássicas da Índia, através dos itens de repertório criados nos anos 1950 do século passado. Andrade (2007) ressalta a possibilidade de surgir uma dança hindu' brasileira em um futuro não distante:

\begin{abstract}
É interessante observar o modo de apropriação da dança hindu pelos brasileiros. Essa forma de arte, tão antiga quanto rica, foi internacionalizada a partir de uma jornada que incluiu a identificação com valores estéticos [...], respeito a tradição religiosa [...] e guarda e promoção das mesmas. [...]. Assim como é previsível que inovações só venham a acontecer no momento em que se estabelecer, de fato, uma dança hindu brasileira (Andrade, 2007, p. 291).
\end{abstract}

Além do coreógrafo Ivaldo Bertazzo (1949 - ), precursor da divulgação da dança Odissi no Brasil a partir dos anos 1970, cujos trabalhos como Samwaad rua do encontro (2003) e Kashmir Bouquet (2007) promovem diálogos explícitos entre danças indianas e coreografias autorais, outras produções brasileiras em dança surgem desvinculadas tanto da sacralização e tradição da arte indiana, como do artista que foi à Índia para aprender a técnica.

Dando sequência à descrição do vídeo, quando o pai em sua poltrona cai em África, um grupo de tribais enfrenta uma alcateia de leões. Imediatamente após a queda, Michael Jackson já faz parte do grupo, e dançam uma coreografia. O videoclipe adota uma estratégia de "revista", isto é, Michael Jackson e o grupo correm para a lateral direita, onde um novo cenário, de outro país, está colocado.

${ }^{10} \mathrm{O}$ autor utiliza o termo dança hindu como ligação direta das tradições pertencentes à filosofia hinduísta. 
Monten (2015) conceitua "revista"11 como uma das formas usadas por coreógrafos para integrar diferentes linguagens.

Após África aparecem dançarinas balinesas em um estúdio cromo, depois Michael Jackson vai para o oeste americano e passa a cantar e interagir com a dança de índios apaches, e na sequência faz um duo com a bailarina Yamuna Sangarashivam, trazendo pioneiramente, no universo dos videoclipes, a dança clássica indiana Odissi. A música, que retrata diferenças raciais já no próprio título (Preto ou Branco), pode ser percebida como um manifesto sobre o preconceito racial presente na sociedade estadunidense, que, mesmo formada por nacionalidades de todo o mundo, demonstra uma contínua perseguição a grupos étnicos não brancos, e as coreografias representativas de algumas destas nações surgem ao longo do vídeo. Depois da dança Odissi ele subirá e descerá vigorosamente com bailarinos cossacos, sob flocos de neve, em frente ao Kremlin, e então se revela que a narrativa se passa dentro de um globo de neve segurado por dois bebês, um preto e um branco, sentados sobre o planeta Terra.

Após a cena dos bebês vem um interlúdio, no qual o personagem de Macaulay Culkin volta a aparecer em uma escadaria com crianças da mesma idade, pretas e brancas, dublando um rapper. Após esse interlúdio, Michael Jackson aparece dançando em frente à tocha da Estátua da Liberdade. E, por fim, vem a parte tecnologicamente inovadora para a época, em que pessoas de diferentes etnias

${ }^{11}$ Segundo o autor: O que é de maior interesse para os fins deste capítulo, no entanto, são as formas que os coreógrafos têm encontrado para incorporar tantas línguas diferentes em sua própria linguagem. Eu identifico três estratégias básicas. Uma eu vou chamar de "revista": encadeamento de uma série discreta de episódios de dança, muitas vezes contrastantes - frequentemente com uma pequena pausa para aplausos e mudanças de roupa entre um episódio e outro - como se pode ver em Ziegfeld Follies ou em uma apresentação dos Ballets Russos de Diaghilev. Uma segunda forma de combinar ingredientes eu chamo de "fusão": misturar elementos de danças díspares tão minuciosamente que eles parecem se fundir em uma nova forma de dança híbrida. A fusão parece ter prevalecido durante algum tempo; um exemplo que pode ser lembrado é o uso que Katherine Dunham faz de elementos caribenhos em sua Cuban Suíte, ou as danças étnicas estilizadas usadas no segundo ato de ballets clássicos do século XIX, como O Lago dos Cisnes. Embora se observe um aumento acentuado no valor da estratégia de fusão nas últimas décadas, eu considero ser esse um processo onipresente na história da dança europeia-americana: é a forma mais comum pela qual as influências são assimiladas e conciliadas. Uma terceira estratégia para combinar ingredientes - e o foco do meu ensaio - eu chamo de "ecletismo". Em coreografias mais recentes, elementos de danças combinados nem sempre parecem ser tão nitidamente separados, como em uma revista, nem se encaixam tão bem como em uma fusão. Uma analogia culinária pode ser útil. Em vez de ser apresentada como um conjunto de travessas, cada uma com um vegetal diferente ou, de outro lado, uma travessa com um molho bem cozido ou um purê, encontramos aquilo que na culinária francesa se chama compota - uma mistura de ingredientes, cada um mantendo um pouco de sua cor original, textura e sabor. É mais exatamente esse fenômeno - análogo à compota - que eu defino por ecletismo, e que eu acredito ser uma característica distintiva da dança pós-moderna (Monten, 2015, p. 112). 
vão se transformando umas nas outras. Interessante notar que, em todo esse último trecho, aparece somente o busto das pessoas (colo, pescoço e rosto), enquanto dublam o cantor, que já não aparece. A última pessoa que aparece é uma mulher negra e ela é mostrada de corpo inteiro, em making of, trazendo ao videoclipe um tom de realismo que surpreende. Também é importante notar que este momento do videoclipe possibilita, além de uma discussão de cunho étnicoracial, uma leitura sobre transgeneridade, pois as pessoas vão se transformando umas nas outras, com homens se transformando em mulheres e vice-versa, de forma muito natural, passando uma mensagem de equidade também em relação a questões de gênero. A dança clássica Odissi acontece a partir do 3'27" até o 3’47"'12 e ambos, Michael Jackson e Yamuna, dançam em sequências conjuntas, num dueto "Pop-Odissi", no qual giros ou bramaris, locomoções ou charise ainda poses ou bhangili3 são apresentadas, numa combinação inédita na linguagem de videoclipe, trazendo a dança Odissi, ainda muito desconhecida fora da Índia, para a vitrine do ocidente.

Neste breve recorte de tempo do vídeo, a cena da dança Odissi traz à contemplação, como as descritas no tratado Shilpa Prakash, figuras das alasaskanyas ${ }^{14}$, entre alguns giros e outros passos presentes nas sequências da coreografia Batu, que surgem rapidamente e encantam quem as vê.

Desde o início do videoclipe, o artista Michael Jackson dança vigorosamente, expressando na maior parte de seus diálogos com outras danças certa agressividade, como um protesto dançado de acordo com a letra da música. Somente quando se apresenta em duo com Yamuna, criando diálogos com a dança Odissi, tanto sua expressão quanto movimentação se tornam suaves, líricas e até ingênuas, características pertencentes ao estilo Odissi, que, de acordo com o tratado Natya Shastra, é identificado pela maior presença de intenção lasya do que tandava.

\footnotetext{
${ }^{12}$ O vídeo completo está disponível em https://youtu.be/pTFE8cirkdQ. Acesso em: 07 set. 2020.

${ }^{13}$ Brahmaris, charisebhangi são nomenclaturas básicas da movimentação da dança Odissi.

${ }^{14}$ Serão definidas e conceituadas no próximo item, mas referem-se a esculturas de figuras femininas em
} templos indianos. 
A função determinante das alas akanyas: imobilidade e presença resiliente das esculturas femininas na dança Odissi

Iniciemos pela observação postural das alasa kanyas (Figura 1), esculturas de figuras femininas contidas em inúmeros templos no vasto território indiano, também relatadas na literatura sânscrita, e fonte de inspiração para a fundamentação, nomenclatura e metodologia da dança clássica indiana Odissi, originada na costa leste da Índia, por volta do século II a.C., no atual estado de Odisha.

Figura 1 - Exemplo de alasa kanya: Darpana

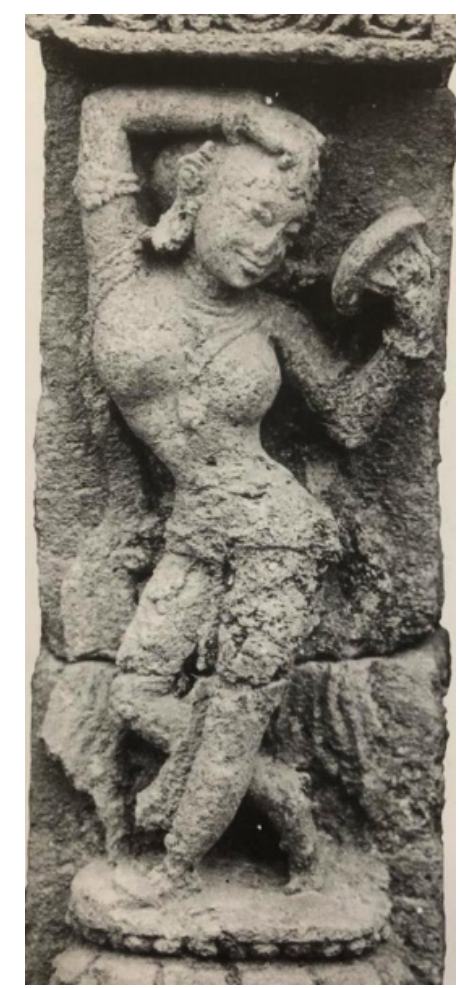

Fonte: Hejmadi, Patnaik, 2012, p. 17

As figuras de mulheres esculpidas em pedra ${ }^{15}$ são destacadas aqui nos seus diálogos e contágios entre multilinguagens artísticas de Odisha, como a pintura

\footnotetext{
${ }^{15}$ Há uma variedade de imagens femininas representadas no programa decorativo e iconográfico do templo. Os diferentes tipos de mulheres retratadas nas paredes do templo incluem divina, semidivina e secular. As imagens divinas são destinadas à adoração e incluem imagens de deusas como divindades autônomas e como consortes das diferentes formas da Santíssima Trindade Hindu - Brahma, Vishnu e Mahesh (Shiva). Depois, há imagens de apsaras, sursundaris, nagis, alasa kanyas e assim por diante. São diferentes tipos de mulheres, cada uma com aspectos diferentes encontrados na arte e na literatura. As alasa kanyas são popularmente conhecidas como nayikas em outras partes do país e na literatura sânscrita, que transborda de poemas e histórias que exaltam a beleza das nayikas (Sharman, 2020, p. 1).
} 
pattachitra, literatura poética kavya, e na própria dança Odissi, seja em coreografias de dança pura, nritta, ou expressiva, nritya, demonstradas individual ou coletivamente, em posturas esculturais fixas ou em suas ações determinantes em movimentos coreografados, bem como acerca de sua presença no videoclipe da música Black or White, de 1991, do artista Michael Jackson (1958-2009), no qual algumas das alasa kanyas da dança Odissi aparecem em cena, através da dança Odissi, realizada em duo com o artista.

Durante os séculos III a.C e XIII d.C. o estado de Odisha, Índia, desenvolveu a escola de arquitetura conhecida genericamente como Kalinga ${ }^{16}$, na qual a presença das alasa kanyas é amplamente percebida nos templos construídos ao longo deste período. Enumeradas em 16, as alasa kanyas, de acordo com inúmeros tratados sobre forma e disposição de objetos na arquitetura clássica dos templos, sendo o mais importante deles o Shilpa Prakasha, de Ramachandra Mahapatra Kaula Bhattaraka (Odisha, séc. XI d.C), as jovens esculpidas deveriam estar presentes nos conjuntos arquitetônicos templários, na entrada ou nos nichos encravados nas paredes dos mesmos, atuando em sua imobilidade e presença como um rito de purificação sensorial daqueles que por entre as mesmas circulassem. Essas esculturas femininas, quando coreografadas na dança clássica Odissi, mesmo que fora do templo, provocam ainda o propósito inicial de sua existência, atravessando geografias e temporalidades, em sutis movimentações ou pausas dramáticas posturais, promovendo na audiência um estado de encantamento e curiosidade acerca dessas figuras em suas imobilidades móveis.

Para a pesquisadora austríaca radicada nos Estados Unidos, professora da Universidade da Pensilvânia, e responsável pela doação de diversas obras de esculturas da arte Kalinga ao museu de artes da Filadélfia, Stella Kramsrich (18561993), que se aprofundou na observação, preservação e memória do vasto legado da arte arquitetônica de Odisha, tornando-se assim um dos grandes nomes ligados

${ }^{16}$ Kalinga foi um vasto território na antiguidade indiana que compreendia os atuais estados de Odisha, Madya Pradesh e Andra Pradesh, localizados no centro leste da Índia. Após inúmeras invasões e reestruturações, sua presença em epopeias indianas como o Mahabharata (autoria atribuída ao sábio Viasa, séc. III a.C) e Indica, do escritor e pesquisador grego Megasthenes (350 a.C - 290a.C.), comprova sua ancestralidade e participação na história da formação da Índia. Kalinga teve autonomia comercial, marítima e cultural em conquistas além do próprio território através de navegações no oceano Índico e deixou um vasto complexo arqueológico, literário e artístico. Disponível em: https://pt.wikipedia.org/wiki/Kalinga_(\%C3\%8Dndia). Acesso em: 07 set. 2020. 
à arte de Odisha e Bengala, as kanyas prendem a atenção de quem as vê e atuam como interlocutoras entre deuses e humanidade:

Nada é deixado ao acaso nesta arte, que tem plena consciência de seus meios e objetivos. Os volumes são delimitados por planos e linhas quase que matematicamente definidas. Cada sujeito tem seu lugar próprio e cada lugar tem seu significado, bem como cada figura sua função. As serviçais e mensageiras da Grande Deusa oferecem seus encantos, olhares, movimentos e símbolos. Quanto mais absorvidos eles parecem em sua performance, mais provocantes eles são. Sua função é despertar o devoto (adorador), atrair e prender sua atenção e, assim, conduzi-lo de volta ao centro de onde emergiram ${ }^{17}$ (Kramsrich, 1954, p. 43).

As alasa kanyas são facilmente identificadas nos templos de Bhubaneswar, capital de Odisha, e arredores. Trazidas para a técnica da dança Odissi, principalmente pelo grupo Jayantika, de revitalização da mesma, na metade do século XX, à época da independência da Índia dominada pela Inglaterra entre 1858 e 1947, e anteriormente pelo império islâmico Mughal, entre 1526 a 1857, como resgate e afirmação cultural, dentro da própria Índia. Denominadas como Alasa, numa alusão a todas elas, ou Naribhanda, fileira de mulheres, cada uma traz um caráter de identificação próprio, que raras vezes encontra-se híbrido numa mesma figura esculpida. Aparecem em coreografias de repertório tradicional da dança Odissi, algumas mais vezes, outras menos, mas essenciais para o aprofundamento do estudo e conhecimento da técnica da dança. Com um ar de indolência, de distanciamento do tempo presente, absortas em suas atividades, as Kanya, Surasundari, Naribhanda ou ainda Nayikas ${ }^{18}$, nos mostram o universo feminino presente na característica lasya ${ }^{19}$ do estilo Odissi, um dos oito reconhecidos como dança clássica da índia. De acordo com o tratado ShilpaPrakash, elas são

\footnotetext{
${ }^{17}$ Nothing is left to chance in this art, which is completely aware of its means and purpose. The volumes are enclosed by planes and lines which are almost mathematically defined. Each subject has its proper place, each place its meaning, and each figure its function. The maids and messengers of the Great Goddess offer their charms, glances, movements and symbols. The more absorbed they seem in their performance, the more provocative they are. Their function is to stir the worshipper, to awaken, attract, and hold his attention, and thus lead him back to the centre from where they have emerged. (Tradução nossa).

18 Kanya (jovem mulher), Surasundari (beleza celestial), Naribanda (fileira de mulheres) e Nayikas (heroínas, protagonistas da obra artística) são termos equivalentes para referência do conjunto.

${ }^{19}$ Lasya e Tandava são conceitos da língua sânscrita inerentes às artes performáticas da Índia, respectivos às movimentações suave e vigorosa, feminina e masculina do casal de deuses Parvati e Shiva em sua dança cósmica.
} 
conhecidas e necessárias por suas ações.

\section{Fileiras de mulheres ou Naribhanda - da escultura ao vídeo clipe}

Para facilitar a visualização, organizamos em um quadro a descrição de cada uma das alasa kanyas que aparecem no videoclipe. O estudo aprofundado da presença determinante das kanyas no processo de revitalização das danças Odissi e Chhau, bem como na construção da identidade cultural e artística do povo de Odisha, dentro da Índia independente em meados do século XX, está presente na pesquisa de doutorado em andamento da primeira autora. Neste quadro, incluímos, ao lado das alasa que aparecem no videoclipe de Michael Jackson, a minutagem, para o leitor que se interesse por localizar no próprio videoclipe ${ }^{20}$.

\begin{tabular}{|c|c|c|}
\hline Nome & Descrição & Minutagem \\
\hline $\begin{array}{l}\text { Torana - a que } \\
\text { está sob um arco }\end{array}$ & $\begin{array}{l}\text { Com os braços para cima, formando um arco e um dos } \\
\text { pés cruzando à frente do outro, esta postura dá uma } \\
\text { característica de alongamento do corpo, ao mesmo } \\
\text { tempo de uma entrega a esse estado de descanso. } \\
\text { Muitas vezes estão na entrada dos templos, sob os arcos } \\
\text { (toranas) ou entre uma sala e outra, nas abóbadas } \\
\text { divisórias do templo, representando assim, com seu } \\
\text { corpo, o próprio arco da arquitetura. Uma característica } \\
\text { a ser observada é a direção das palmas das mãos: se } \\
\text { para baixo, é chamada de Spandita (absorta em si } \\
\text { mesma), e se as palmas estão viradas para cima, seu } \\
\text { nome é chhandita (mente em atividade). }\end{array}$ & 3'44" \\
\hline $\begin{array}{l}\text { Mardala }{ }^{21} \text { - a que } \\
\text { toca percussão }\end{array}$ & $\begin{array}{l}\text { Se Odisha tem um som, este som é o toque da mardala. } \\
\text { Desta forma, a Mardala Kanya não é apenas uma } \\
\text { percussionista, e sim aquela que prepara o tapete } \\
\text { sonoro para o ritual da dança acontecer. Ela aparece } \\
\text { comumente com os joelhos flexionados e voltados para } \\
\text { fora, na postura de chowka }{ }^{22} \text {, e suas mãos mencionam }\end{array}$ & $3^{\prime} 40^{\prime \prime}$ \\
\hline
\end{tabular}

${ }^{20}$ A minutagem refere-se a este hiperlink: https://www.youtube.com/watch?v=F2AitTPI5UO

${ }^{21}$ Mardala é um tambor típico de Odisha, também chamado de pakhawaj. Com dois lados para ser tocado, ele é disposto horizontalmente, e as mãos, simultaneamente, tocam ambas as partes, compondo a música da região, cujas sílabas sonoras extraídas destas batidas formam a estrutura silábica inerente ao aprendizado e execução da dança Odissi.

${ }^{22}$ A postura do quadrado, presente na dança Odissi, é uma representação da divindade totêmica Jagannatha, cultuada no estado de Odisha. Tecnicamente associada à dança vigorosa presente no estilo, em oposição à postura do tribhanga, considerada suave. A partir da postura inicial tanto do chowka quanto do tribhanga foram desenvolvidas sequências de treinamento em dez exercícios cada, que constituem os fundamentos da estrutura da dança Odissi e se ampliam para a criação coreográfica. 
existir um tambor entre elas, ou ao tambor ser esculpido, muitas vezes, uma das pernas está levantada, enquanto uma das mãos também, trazendo a ideia de dança e música em execução simultânea.

Darpana - a que se admira no espelho
Olhando-se no espelho (darpan), esta Kanya traz em seu semblante um momento de prazer ao se admirar. Seus cabelos têm ornamentos, assim como seu corpo. Brincos, colares, enfeites de testa são muito mais presentes em Darpana. Ao se olhar ela traz à atmosfera um momento de apreciação sutil do delicado cotidiano feminino ancestral. É talvez a kanya mais reproduzida em dança expressiva no estilo Odissi e a representação máxima da qualidade feminina deste universo das Nari Bhanda.

Esta kanya vem sempre acompanhada de papagaios ou mynah (maina) e utiliza um de seus braços como suporte de apoio para o pássaro. Na literatura sânscrita os papagaios e mynahs trazem mensagens e agem como interlocutores de casais ou amigas. Segundo a cultura tradicional de Odisha é de muito bom agouro ver um casal destes pássaros, comumente relacionados como mensageiros do plano divino.

As kanyas são figuras muito mais comuns no repertório coreográfico de Odissi e muitas vezes não contam histórias, surgindo como quem são, em sua complexidade, dentro da chamada dança pura ou sem significado. Sua função ainda é trazer à contemplação a graciosidade e ancestralidade presentes nos antigos tratados de devoção através das formas. Especificamente em uma das coreografias de repertório conhecida como Batu, composta em honra ao deus Shiva, na forma de Batuka Bhairava, as naribhanda ou fileiras de mulheres aparecem, uma após a outra, preenchendo o espaço cênico, como estátuas vivas de um templo imaginário de forma prazerosa.

Criada pelo mestre Guru Kelucharan Mohapatra (1926-2004), um dos integrantes do grupo Jayantika, Batu foi inspirada tanto na observação direta das esculturas do templo de Konark, litoral de Odisha, numa análise profunda postural quanto à posição de pés, direção dos vetores corporais, gestos, direção dos olhos, expressão facial e ornamentos, como também na dança dos meninos gotipuas ${ }^{23}$ de sua vila natal. A partir de evidências esculturais arqueológicas, sobre possíveis

${ }^{23}$ Gotipuas são jovens bailarinos que se apresentam vestidos como meninas, e a característica principal de sua dança é a vigorosidade acrobática. O grupo Jayantika, em 1950, une a forma de dançar gotipua com a tradição das dançarinas devocionais maharis, criando a dança Odissi como é conhecida desde então. 
sequências de movimentação e ritmo, foram coreografadas novas movimentações de uma tradição recém desenhada, com mistura de elementos culturais regionais, acrescida de textos clássicos como referência interpretativa para sua execução artística. Dos itens de repertório surgidos nessa época, Batu ainda hoje é considerada a coreografia mais difícil de ser executada, não só em relação às intrincadas sequências de passos ou padas, associados à tala (canto silábico), mas às transições posturais, que vão desde athibhangas, como o uso de bhumibramari (giros no chão) raramente executados, conhecido como charuparschwachira. Não é por acaso que esta tenha sido a coreografia escolhida por Yamuna Sangarashivam, aprendida com seu mestre Gangadhar, que por sua vez aprendeu com o autor da coreografia, para compor com o videoclipe do astro pop, visto ser uma oportunidade de demonstrar toda a virtuosidade que a dança Odissi pode ter.

Também não é por acaso que a dança Odissi surja neste cenário dos anos 1990 como a nova descoberta indiana no meio artístico. Outras danças da Índia já haviam chegado à Europa e Estados Unidos no final do século XIX e início do século XX, em interlocuções artísticas não menos importantes, mas onde a Índia era ainda colônia da Inglaterra. O exotismo de suas danças fazia parte da propaganda acerca do império britânico relativo às suas colônias, onde eram exploradas tanto em matéria-prima, em ações escravagistas, em subjugo de todo o tipo, e foco de análise comportamental sob a ótica preconceituosa do olhar europeu sobre seus modos de existência e relações sociais. Com a independência das últimas colônias, sendo a Índia uma delas, e a criação e expansão da indústria fonográfica e cinematográfica em todo o mundo a partir do início do século XX, a mobilidade das artes tradicionais de África, Oceania e Ásia tornaram-se audíveis, e visíveis, em qualquer lugar do planeta. Os vídeos das turnês de artistas asiáticos funcionavam também como uma ampliação do público que poderia assistir espetáculos complexos, não em tempo real, mas em centros de cultura e ensino. A indústria do videoclipe que surge na década de 1980, nos Estados Unidos, como um segmento decorrente do caminho acelerado dos registros sonoros e visuais, difusores de trabalhos artísticos dos pioneiros The Beatles, no Reino Unido, a partir dos anos 1960, contribui para a disseminação de modalidades distintas das vanguardas europeias, ditames de comportamentos. Unindo tais registros à 
estética da linguagem cinematográfica, com seu lançamento oficial na MTV Musical Television Awards, inicialmente nos Estados Unidos e posteriormente ocupando todo o mundo, surge este novo espaço de difusão artística.

Kelucharan Mohapatra, autor da coreografia Batu, é um exemplo de um artista, e consequentemente de sua obra, que surge em conjunto com a evolução rápida da indústria fonográfica e cinematográfica, simultânea à independência da Índia. Da tradicional vila natal Raguraj Pur, em Odisha, sem iluminação elétrica até os anos 1950, tem seu encontro com o ocidente em festivais europeus, patrocinados pelo governo indiano, nos anos 1960 e, na década seguinte, encontrase com o diretor italiano Eugenio Barba e seu teatro antropológico. A dança Odissi desponta muito rapidamente nesta década industrializada para o mundo artístico fora de Odisha através de registros fotográficos e audiovisuais oriundos das turnês conjuntas com o grupo teatral de Eugênio Barba, com sede na Dinamarca, e percorrem não somente a Europa, mas também as Américas, tornando o estilo Odissi, desconhecido na maior parte da índia, um fenômeno da arte clássica recém-descoberta para os próprios indianos. Em 1975, em Paris, a produtora francesa Ariane Segal (1917-2011) lança o trabalho fonográfico L'Inde Musique Traditionelle de Danse Odissi, com a participação de Guru Kelucharan Mohapatra tocando pakhawaj, em 6 faixas que compreendem a estrutura de um repertório tradicional do espetáculo da dança Odissi. ${ }^{24}$ Enquanto na Europa artistas como Jerzy Grotowski (1933-1999), Eugenio Barba (1936 - ), Peter Brook (1925 - ), Ariane Mnoushkine (1939 - ) e Patrice Pavis (1947 - ) buscavam as artes tradicionais de África e Ásia como fonte de aprofundamento artístico e ritualístico, fora do estruturalismo engessado europeu, posteriormente nos Estados Unidos vemos John Cage (1912-1992) e Richard Schechner (1934 - ),entre outros, não somente acolhendo a vanguarda europeia, como as transformando. Para Schechner (Ligiéro, 2012) a juventude americana dos anos 1960 - que, como conceito, se amplia até os anos 1980, onde ele próprio se inclui-, foi contagiada por conceitos filosóficos asiáticos:

[...] é um período marcado por um certo tipo de pensamento utópico, um sentimento de que as coisas podiam mesmo mudar e ser melhores; e por uma explosão de cultura juvenil com o otimismo que lhe está

${ }^{24}$ No estado de Odisha, nesta época, não havia registro comercial da música que acompanha a dança Odissi. 
associado. E o confronto direto com a autoridade em si. Os nossos inimigos eram o racismo, o tráfico de armas, a opressão colonial, a pobreza imposta pela distribuição desigual de riqueza. Éramos contra muitas das leis injustas do Estado. E nas artes havia uma revolução semelhante e correlacionada: a oposição aos cânones estéticos [...]. E também os soldados americanos que foram para a Europa e a Ásia lutar voltaram trazendo com eles uma série de ideias "estrangeiras" que rapidamente prosperaram nos EUA. De novas comidas ao Yoga e ao Zen, as culturas estrangeiras educaram minha geração. [...]. E depois, nos anos oitenta, as questões de gênero e de identidade começaram a ganhar importância: feminismo, direitos gay, lésbicos e transexuais...e muitas outras [...]. O que emergiu nos Anos Sessenta não foi a Europa na América ou a Ásia na América, mas sim uma poderosa fusão Europa - América Ásia (Ligiéro, 2012, p.31).

Dos anos 1960 aos 1980, através da difusão tecnológica dos saberes, a reflexão teórica (e prática) acerca de tratados herméticos de antigas tradições chega (posteriormente) aos centros de ensino das artes cênicas também nas grandes capitais da América Latina, onde a interculturalidade também se torna um movimento artístico, possibilitando trocas, contágios e adaptação das referidas tradições. Também é a partir deste momento que olhares específicos no recémcriado campo chamado estudos da performance, bem como da etnomusicologia (em estudos musicais) ou etnocenologia (em estudos da cena)são cada vez mais aprofundados, constituindo epistemologias específicas de investigação e suas reverberações em diversos campos que, oriundos da antropologia tradicional, também renovada e desprendida das pesquisas sob óticas unilaterais dos colonizadores, promovem reflexões identitárias e revelam falas há muito caladas nos processos colonizatórios, nos quais coletivos foram silenciados através da escravidão e guerras pelo poder.

Para Patrícia Aschieri (2018), professora de antropologia do movimento da Universidade de Buenos Aires, o estudo antropológico das cenas demonstra o fortalecimento de ocupação de espaços visíveis ou invisíveis através do uso criativo de transformações nas relações sociais:

Las dinámicas creativas dependerán entonces del lugar que se ocupe en el propio campo cuya posición favorecerá u obstaculizará la posibilidad de utilizar ciertos grados de creatividad para transformar y/o para reproducir patrones y estilos dancístico-teatrales. Asimismo, los participantes de esos campos pueden establecer relaciones con prácticas de otros espacios (declaradas o invisibilizadas), así como 
articular alianzas estratégicas que permitirían alcanzar o reforzar prestigio y autoridad (Aschieri, 2018, p.283).

A geração posterior que surge, nos anos 1990, já mais acostumada com novas tecnologias multimidiáticas, e a indústria de videoclipes (como um segmento crescente ligado diretamente a este público), espalha-se como público consumidor em canais de televisão como a MTV25, porém agora já com uma preocupação de construção narrativa sobre as imagens iniciais dos artistas tocando suas músicas. Os artistas passam a ser os protagonistas de filmes, de histórias de suas músicas, e é neste contexto que a dança Odissi se populariza no clipe Black or White, de Michael Jackson. Ainda que o artista não tenha ido à Índia para pesquisar sua origem, traz à tona uma das muitas manifestações do subcontinente indiano, que, sem identificação específica no trabalho do Rei do Pop, une-se a outras tradições, num apelo também visual da ruptura dicotômica sobre direito, esquerdo; certo, errado e preto ou branco, em uma gama muito visível de alteridades de existências, através de suas imagens e movimentos, numa tentativa de tornar visível outras etnias presentes no solo democrático (e desigual) norte americano.

Vários pesquisadores trazem em seus trabalhos, sob diferentes aspectos, a obra deixada por Michael Jackson. No campo da antropologia musical, desenvolvido a partir da antropologia tradicional e tendo o foco nos estudos específicos de sound studies, muitos estudiosos analisam seu legado quer seja na produção, na qualidade de som, nos diferentes timbres, diferentes fases, sobre a construção do personagem/artista que se mistura com a realidade de sua própria vida e influências de sua música em campos comportamentais da sociedade. Os etnomusicólogos Burnnet e Deivert (2008) ao fazerem uma análise sobre Black or White, apontam que, apesar do segmento de videoclipes ser direcionado ao público jovem, a sociedade adulta norte-americana sente-se incomodada pela influência de Michael Jackson, que, ao chamar a atenção para questões sociais

${ }^{25}$ MTV ou Music Television teve sua inauguração em 1981, na cidade de Nova lorque, Estados Unidos. Com as palavras: "Damas e Cavalheiros, rock' nroll!" numa alusão às palavras ditas sobre imagens da conquista do espaço pelos americanos em 1969, ocorre a estreia deste segmento especializado em vídeo clipes, que perde hoje espaço para a mídia digital. Disponível em https://pt.wikipedia.org/wiki/MTV último acesso em: 25 maio 2020. 
sobre o preconceito racial e diferentes formas de existência - que coabitam não só no território americano, mas em um mundo globalizado -, ironicamente foi acusado de promover violência, maus costumes e comportamento agressivo para a juventude da sociedade estadunidense. O artista precisou reestruturar cenas consideradas agressivas para a classe média americana:

Em um comunicado à imprensa após a polêmica, Michael Jackson emitiu as seguintes declarações: "Me perturba pensar que Preto ou Branco pode influenciar qualquer criança ou adulto a um comportamento destrutivo, seja sexual ou violento. Sempre tentei ser um bom modelo" [...] Black or White foi posteriormente truncado e a versão modificada continuou a ser exibida na MTV (Burnnet \& Deivert, 1995, p. 19) ${ }^{26}$.

De qualquer forma, a polêmica em torno do videoclipe, assim como na própria figura do artista Michael Jackson - que pode ser analisada sob diferentes pontos de vista -, não deixa de trazer à tona o nosso foco central quanto à presença da dança indiana em suas figuras naribhanda, e o fator determinante da presença das mesmas, seja em esculturas milenares de pedra ou na criação coreográfica da dança Odissi e, por conseguinte, sua réplica ao lado do Rei do Pop: promover àquele que as vê uma alteração dos sentidos cotidianos, numa condução a estados extracotidianos, em uma transicionalidade reflexiva para estados de existência.

\section{Em frente às torres do consumismo - fumaça branca}

They print my message in the Saturday Sun

I had to tell them I ain't second to none

And I told about equality and it's true

Either you're wrong or you're right

But, if you're thinkin' about my baby

It don't matter if you're black or white

Numa mistura de dança pop com extrato coreográfico pertencente ao item Batu, ao som do trecho acima, finalizado pelo verso que dá título à música, os

${ }^{26}$ In a press release following the controversy, Michael Jackson issued these statements: "It upsets me to think that Black or White could influence any child or adult to destructive behavior, either sexual or violent. I have always tried to be a good role model" [...] Black or White was subsequently truncated and modified version has continued to be show in MTV. (Burnnet \& Deivert, 2008, p. 19). (Tradução nossa) 
vinte segundos da dança de Odisha acontecem num templo contemporâneo do centro do mundo capitalista, feito na noite fria de uma cidade ocidental movimentada, cujo palco é a calçada que separa duas vias contrárias de uma avenida ocupada por intenso tráfego de automóveis, exibindo grandes torres ao fundo, exalando a fumaça branca, poluente e ininterrupta, cenário no qual as alasa kanyas formam-se rapidamente no corpo da bailarina indiana.

Não é possível afirmar se Michael Jackson opinou na escolha deste extrato coreográfico para compor a cena do trecho escolhido da canção, mas sensivelmente pode-se fazer uma leitura subjetiva da movimentação escolhida e das alasa kanyas demonstradas, trazendo suas funções determinantes, mesmo que desconhecidas pela maioria do público que assistiu e assiste o vídeo clipe, de acordo com a interpretação da ideia do verso. Na dança expressiva, nrtya, onde o refrão vai adquirindo formas poéticas diversas para se referir à mesma ideia, a composição da cena é realizada concomitantemente entre a literatura e dança ${ }^{27}$.

They print my message in the Saturday Sun

- Eles imprimem minha mensagem no Saturday Sun (jornal) -

A dança Odissi no videoclipe é iniciada em posição de chowka, o quadrado, mexendo somente a cabeça horizontalmente, movimento conhecido com gribha ${ }^{28}$ (pescoço). Enquanto a bailarina executa esta sequência de movimentos dos olhos e da cabeça, com expressão facial neutra, Michael Jackson lê um jornal, também na postura de chowka. Ele amassa o tabloide e a bailarina, esboçando um leve sorriso, faz um giro no próprio eixo, um bramari.

I had to tell them I ain't second to none

- Eu tive que dizer a eles que não sou melhor que todo mundo -

27 A letra de Black or White, em inglês, e tradução em português está disponível em: https://www.vagalume.com.br/michael-jackson/black-or-white-traducao.html Acesso em: 06 set. 2020.

28 Este movimento, muito associado à dança indiana, ocorre quando somente a cabeça se movimenta horizontalmente, sendo o pescoço tensionado para que não se desloque. Na dança expressiva representa deleite, prazer, alegria. 
A primeira kanya surge após a afirmação acima. Chamada de Darpana Kanya, uma das mais conhecidas entre todas as kanyas, numa referência direta a Darpana, que em sânscrito é espelho, esta postura é o olhar-se, o admirar-se, o absorver-se em si mesmo. No início do trecho, enquanto Yamuna realiza sozinha esse gesto, Michael está amassando um jornal (Figura 2). A mesma kanya surgirá novamente ao final, com os dois se olhando juntos no espelho (Figura 3). É interessante observar o simbolismo ao analisar essas escolhas em conjunto com - contexto da letra da música: pode-se interpretar que Michael se permite envolver e contagiar por Yamuna, como se as notícias dos jornais perdessem sua importância após a interação, ou como se Yamuna possibilita-se a Michael ver-se refletido em seu espelho, equalizando diferenças a partir de uma perspectiva intercultural.

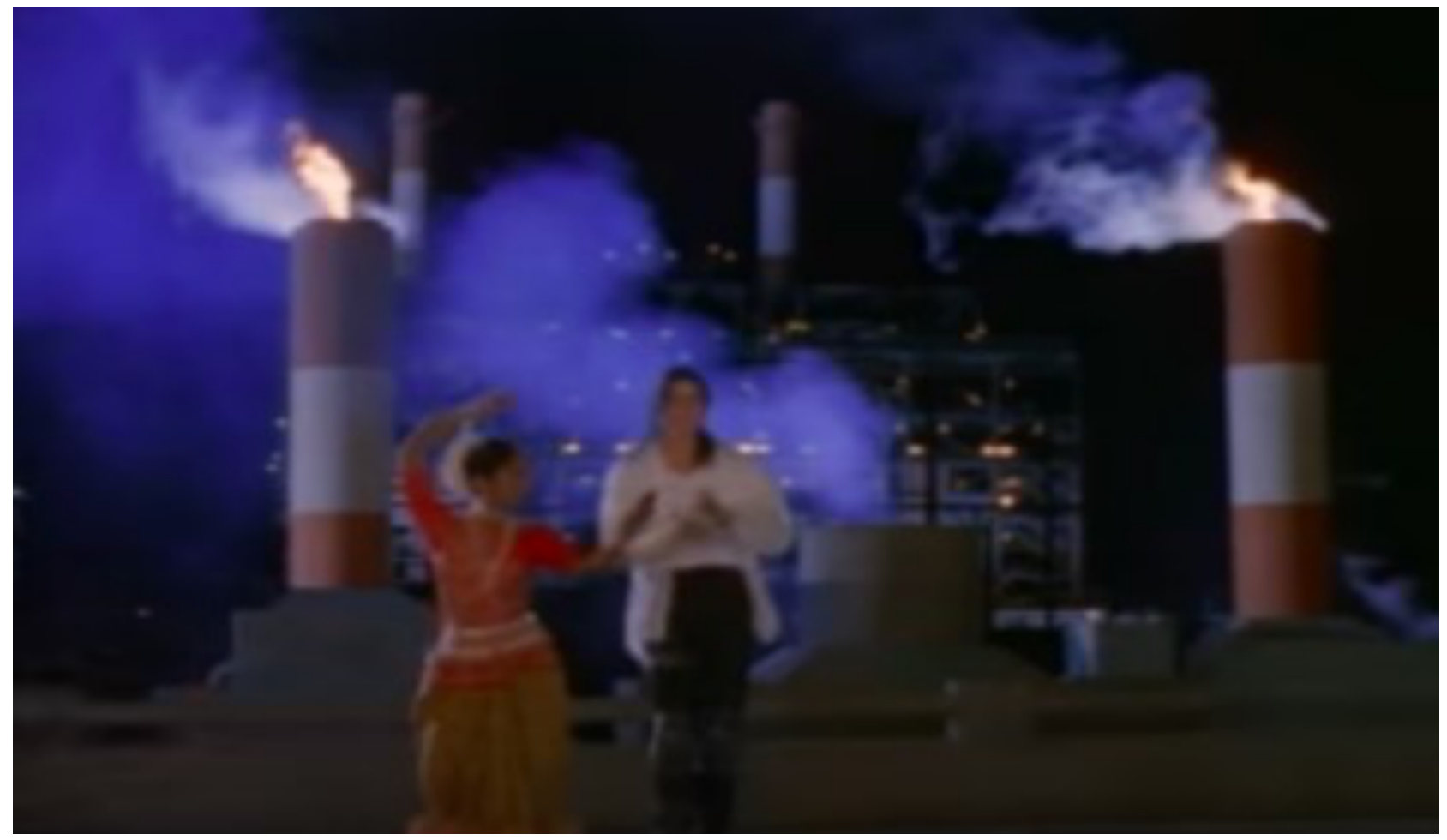

${ }^{29}$ Disponível em: https://www.youtube.com/watch?v=F2AitTPI5U0 
Figura 3 - Kanya 1: Darpana (Final). Frame do videoclipe: Michael Jackson Black Or White (Official Video - Shortened Version) ${ }^{30}$

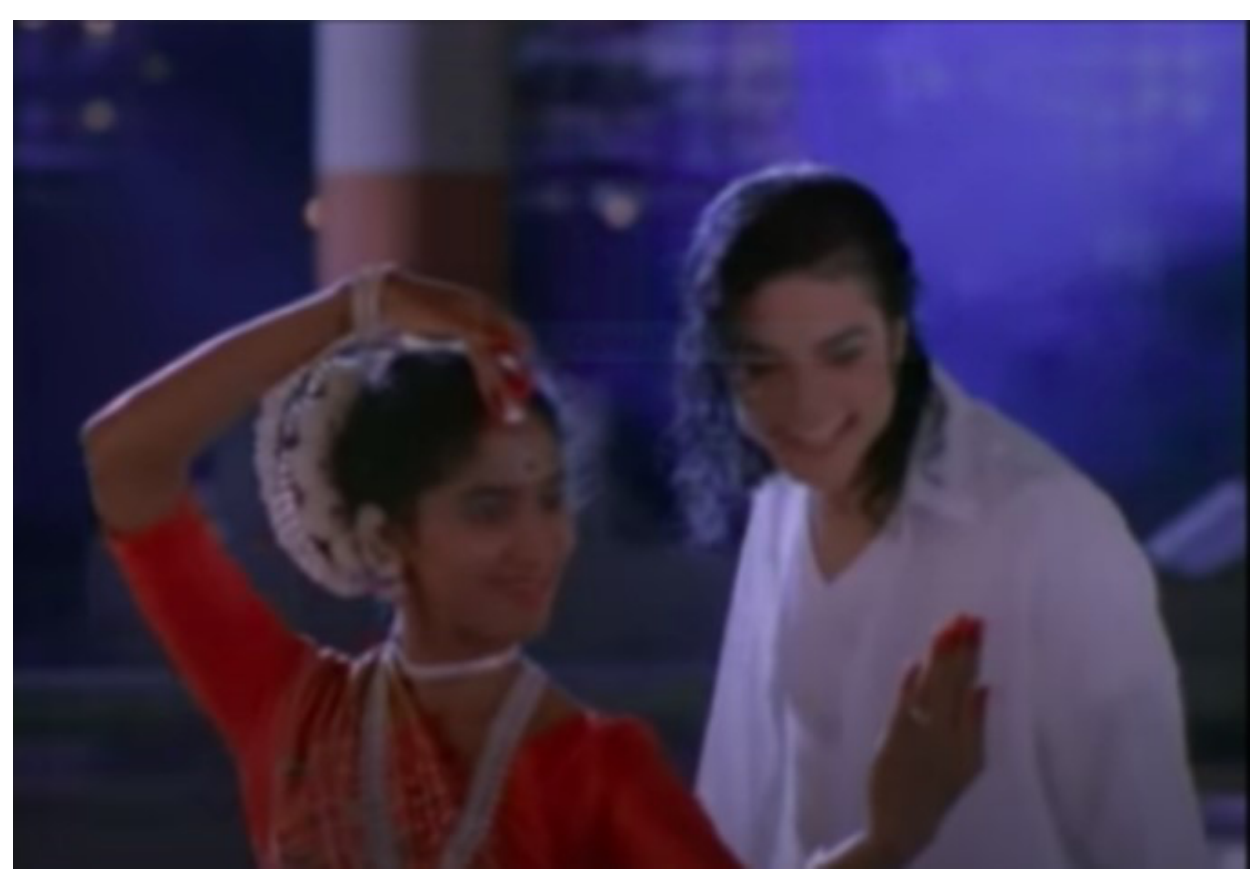

And I told about equality and it's true

- Eu te falei sobre igualdade e é verdade -

Após a rápida execução de Darpana Kanya, recuos também existentes na coreografia Batu, ocorrem simetricamente para a direita e esquerda, em pequenas diagonais marcadas em quatro tempos. Os dois artistas executam igualmente estes recuos, e como em muitas coreografias de repertório Odissi, que retratam o amor cósmico do casal divino Krishna ${ }^{31}$ e Radha, há a menção de um abraço estilizado dentro da técnica, culminando com a troca de olhares e sorrisos, características presentes na rasa sringara, determinada pela bhavarati. ${ }^{32}$

\footnotetext{
30 Disponível em: https://www.youtube.com/watch?v=F2AitTPI5U0

${ }^{31}$ Krishna, em sânscrito, significa negro.

${ }^{32}$ Nove estados determinantes, conhecidos como bhavas, produzem oito diferentes sabores estéticos, rasas. Abhava Rati produz a rasa Sringara, sabor estético relacionado ao amor, é uma das rasas mais conhecidas e executadas na dança Odissi. As outras bhavas e suas rasas são: Hasya (cômico) e Hasya (riso); Karuna (patético) e Soka (tristeza); Raudra (o furioso) e Krodha (raiva); Vira (heroico) e Utsaha (energia); Bhayanak (terrível) e Bhaya (medo); Adbhuta (maravilhoso) e Vismaya (assombro, susto); Vibhatsa (odioso) e Juguptsa (desgosto); Shanta (tranquilidade) e Shama (paz ou conhecimento da verdade (Albergaria, 2020, p. 86).
} 
Either you're wrong or you're right

- Ou você está errado ou você está certo -

Por alguns segundos a música não apresenta letra, somente melodia, e neste momento, após a execução do movimento chamado Parshwalolita, onde as duas mãos pendem para um mesmo lado, displicentes ao lado do quadril, e que logo mudam para a exploração das lateralidades, onde cada uma delas, em gesto pataka ${ }^{33}$, seguem para a execução simultânea do movimento de tocar percussão, em uma caminhada lateral, culminando assim, na segunda kanya presente no videoclipe, a Mardala Kanya. Esta kanya representa o ato de tocar a mardala, trazendo a ideia da sonoridade a esta postura, bem como transitoriedade, e é muito representada na escultura do complexo arquitetônico de Odisha, recebendo grande destaque tanto coreograficamente, nos itens de repertório em dança pura e expressiva, quanto em presença esculpida nas paredes dos templos.

Figura 4 - Kanya 2: Magdala. Frame do videoclipe: Michael Jackson - Black or White (Official Video - Shortened Version) ${ }^{34}$

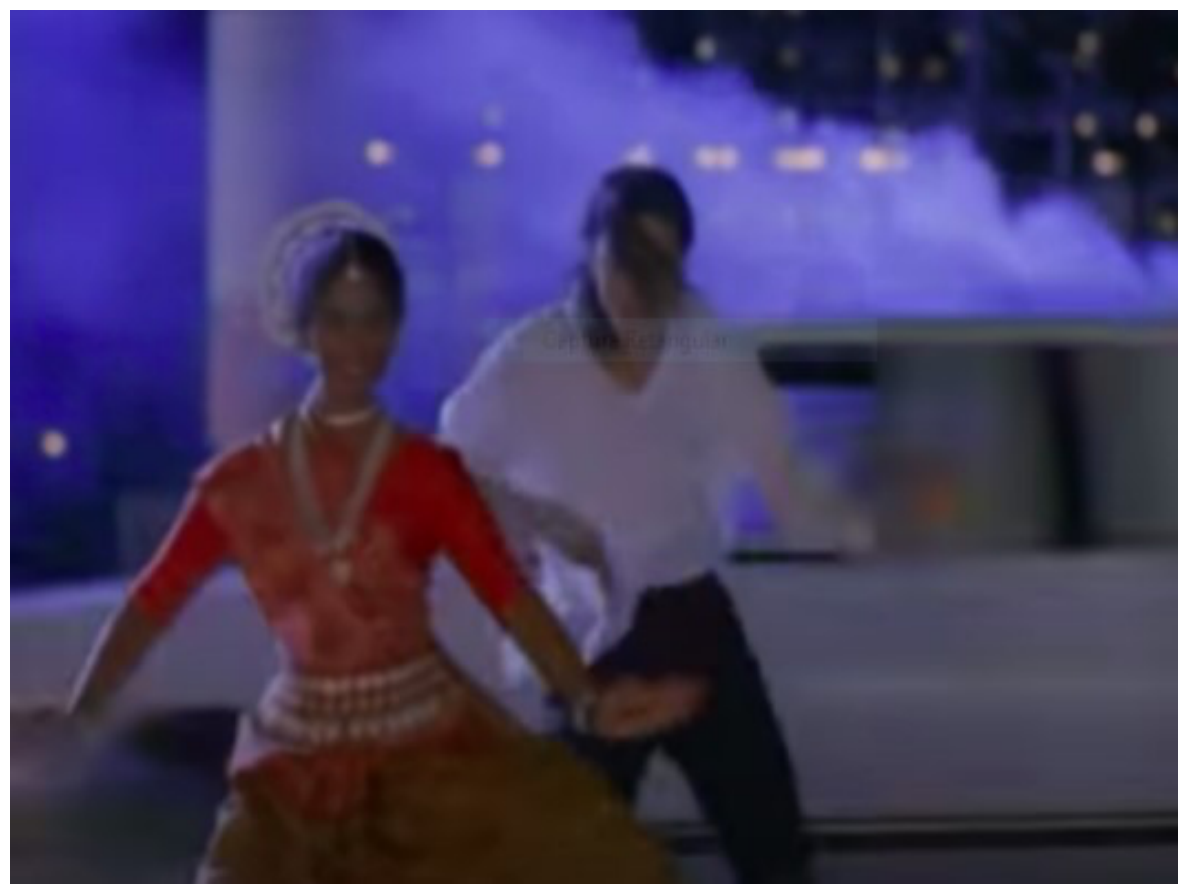

${ }^{33}$ Gesto classificado como simples e introdutor dos muitos presentes no Natya Shastra. Pataka em sânscrito significa bandeira, e o mesmo é executado com os dedos dispostos lados a lado e a palma da mão fechada.

${ }^{34}$ Disponível em: https://www.youtube.com/watch?v=F2AitTPI5U0 
Conhecida como bimukha mayura, esta caminhada simples tem seu gesto executado com as duas mãos simultaneamente, com o mudra mayura ${ }^{35}$, num constante tremular dos dedos das mãos, em direções opostas, mantendo os pulsos de ambas as mãos em uma sutil união, como que ligados por um eixo fixo que permite o movimento das mesmas. Esta ação, que antecede a conclusão da dança Odissi no vídeo clipe, tem o astro do pop acompanhando esta caminhada Odissi com seu estilo próprio.

\section{But, if you're thinkin' about my baby}

It don't matter if you're black or White

Mas, se você está pensando sobre my baby (meu amor)

Não importa se você é preto ou branco

Michael Jackson e Yamuna giram e a bailarina faz uma pausa rápida criando a terceira kanya, numa postura conhecida como pottala, relacionada diretamente com a Kanya Torana, ou aquela que descansa, que espera. Ele continua a dança, realizando alternância de elevação de seus ombros, enquanto mantém os pés parados, um pouco afastados, destacando assim a parte superior de seu corpo em simetria cênica com esta terceira Kanya, que assiste, de forma sorridente, em contínua espera, a esta movimentação. Em direção à conclusão, ao som da frase que dá título à canção, como um sancharibhava ${ }^{36}$ antirracista, conclui-se a apresentação no duo Odissi-Pop com duas posturas fixas: ela executando a quarta alasa kanya, a Sukhasarikha, onde um dos braços, flexionado na altura do ombro e a mão próxima à boca representa um na dança Odissi um pouso para pássaros, mensageiros dos deuses através de seu canto imaginário, presença constante na literatura clássica e devocional de Odisha. Michael Jackson conclui seu canto e sua dança estilizando a dança Odissi com uma das mãos sobre a cabeça e a outra abaixo da cintura, formando uma postura fixa que remete à conhecida

\footnotetext{
${ }^{35}$ Mayura em sânscrito quer dizer pavão ou tudo que se refere ao animal. Muitas vezes este mudra, executado com a união dos dedos anelar e polegar, representa a pena do pavão utilizada como enfeite dos cabelos do deus Krishna.

36 Shancharibhava é a expressão utilizada tanto na literatura quanto nas artes performáticas para designar o verso determinante da poesia ou canção, que ao longo da mesma será repetido textualmente, e interpretado sob formas poéticas e não literais.
} 
30 anos de Black or White: discussões interculturais através das alasa kanyas da dança indiana Odissi no videoclipe de Michael Jackson Andrea Itacarambi Albergaria, Mariana Baruco Machado Andraus

samamukhamayurasya, representante do mundo espiritual e terreno, ligados pelo ser humano, interlocutor de polos opostos.

Figura 5 - Ensaio. Kanya: Torana.

Frame do videoclipe Michael Jackson rehearsing black or white $1991^{37}$

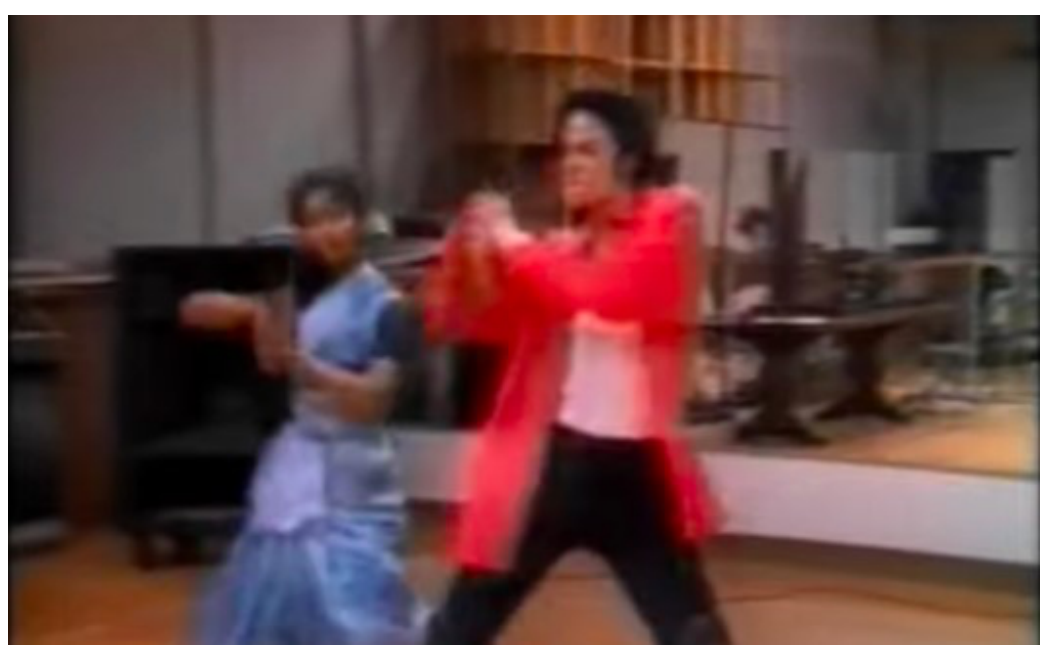

Figura 6 - Kanya 3: Torana. Frame do videoclipe: Michael Jackson - Black or White (Official Video - Shortened Version) ${ }^{38}$

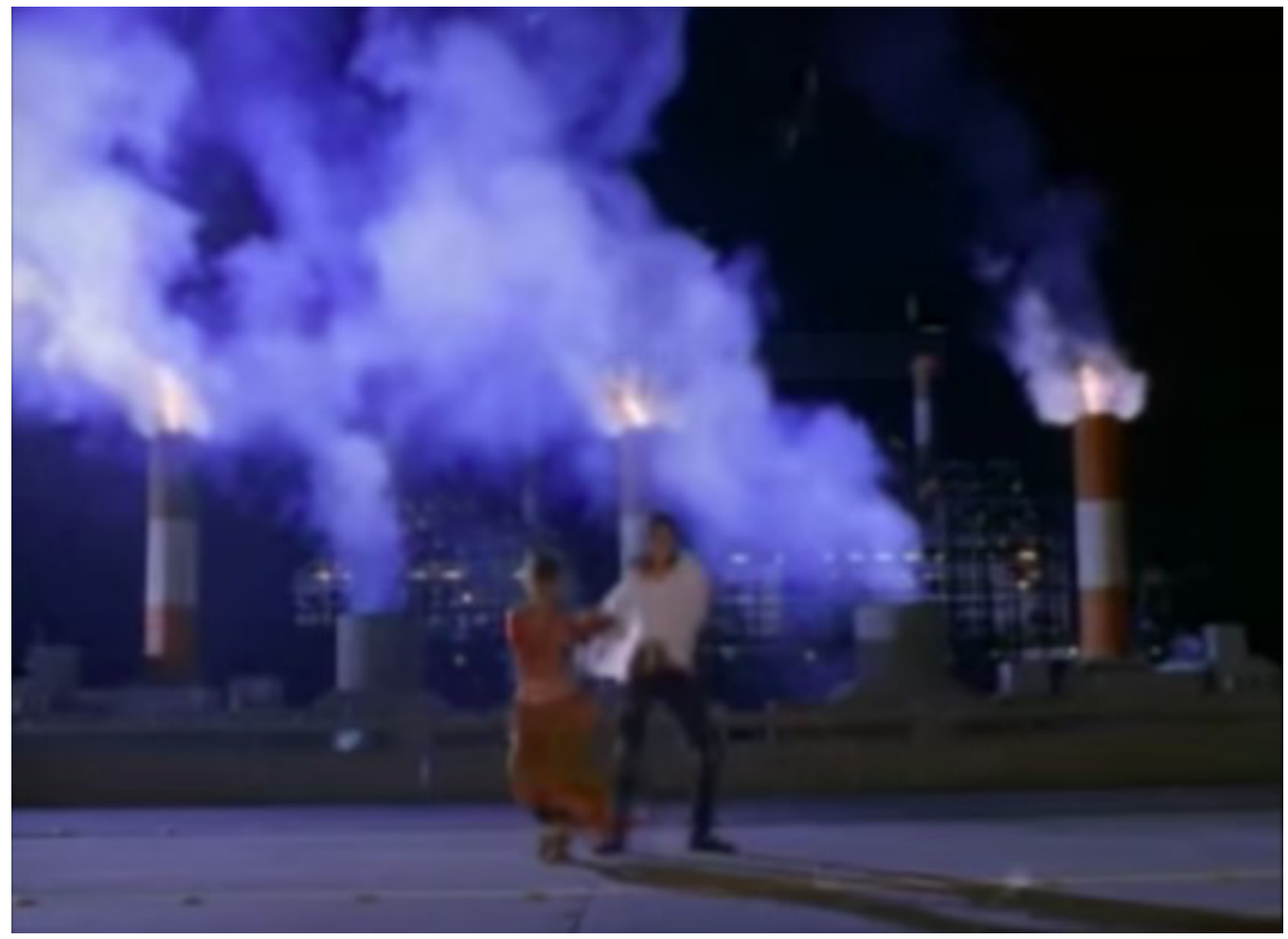

${ }^{37}$ Disponível em: https://youtu.be/RlEreLRqPHM

38 Disponível em: https://www.youtube.com/watch?v=F2AitTPI5U0 
Figura 7 - Kanya 4: Sukhasarika. Frame do videoclipe: Michael Jackson - Black or White (Official Video - Shortened Version) ${ }^{39}$

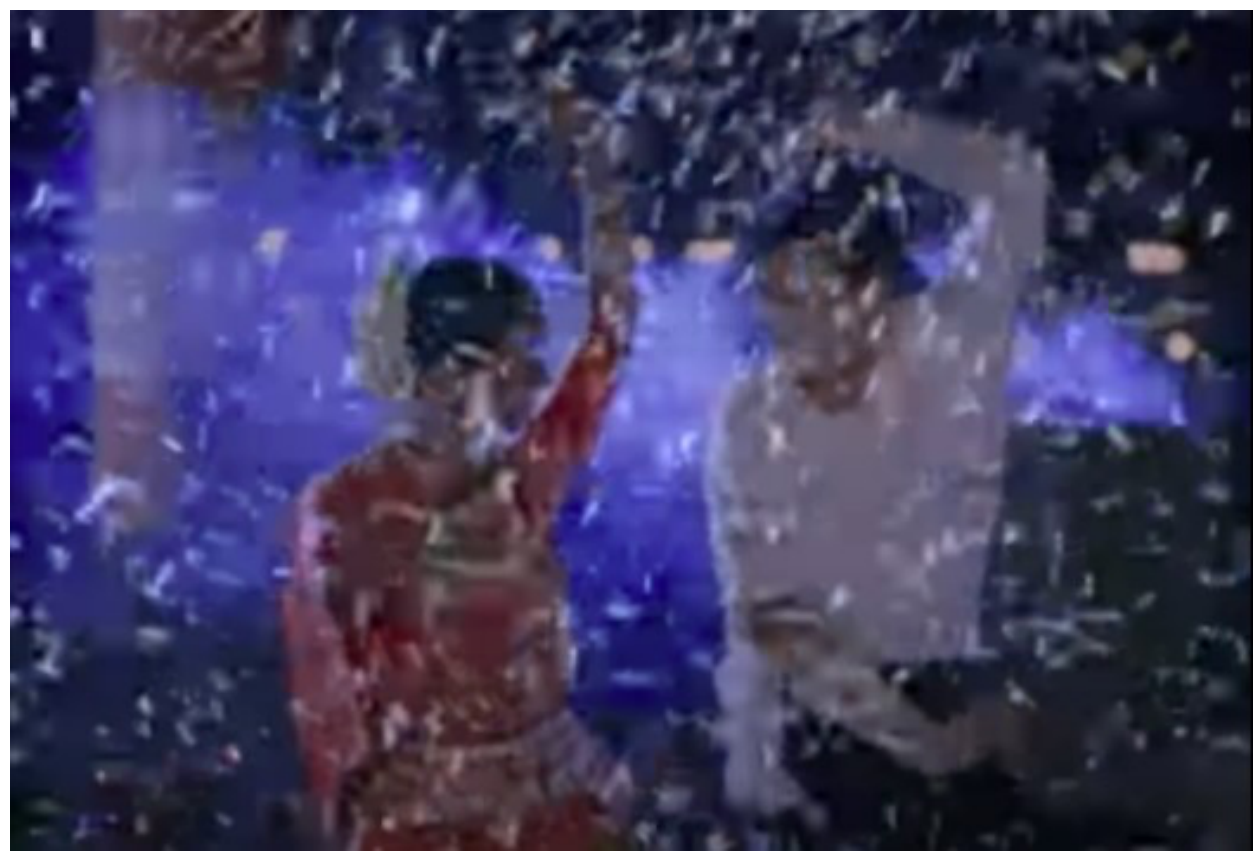

Horizonte cortado em linha, rekha ${ }^{40}$, arquitetura kalinga $a^{41}$ transportada: os carros voam, faróis acesos, riscos de luz sonora rasgando o ar. Dentro das cabines refletoras, semelhantes cabeças em direções opostas, em um ir e vir sem pausa. No palco, mandap cosmopolita da avenida, templo frio de céu noturno: batidas dos pés, sorrisos e olhares aquecem o duo, mistura fina de ancestro-modernidade colonizada latente na calçada de concreto, limite. Os shikaras, torres enormes do cenário fundo, encostam no infinito ralo seus longos dedos de fumaças brancas, brasa em gesto do incenso ofertado: queima ininterrupta de produção infinda. $\mathrm{Na}$ escritura sagrada do agora, vão nos vãos dos céus, sem perfume, produto descartável em combustão, nossas celebrações. Luzes de prédios longínquos, quadradinhos de habitação em pixel, porto seguro de nossas constantes aquisições.

Black or White? Ao usar "or" e não "and", Michael nos provoca a pensar em um lugar entre o preto e branco e, emergindo por esta brecha, vêm à tona as

39 Disponivel em: https://www.youtube.com/watch?v=F2AitTPI5U0

40 Rekha, do sânscrito linha; um dos estilos da arquitetura de construção templária, onde entrada, sanctum santorum e torre principal se alinham.

${ }^{41}$ Ver nota 16 
kanyas, mulheres com seus espelhos, tambores, pássaros, e insolência eternas, girando em alternância em rituais de pedra bruta no espectro das cores, amalgamadas nos instantâneos fotográficos de kala, divino tempo. Na mais recente tecnologia, presente agora no obsoleto passado, registro da arte em voga, lamento disfarçado para sobrevivência e ressurreição.

\section{Considerações finais}

As alasa kanyas são relatadas no tratado das formas Shilpa Shastra e, segundo este tratado, são necessárias para a criação do estado extracotidiano, de observação e contemplação meditativa, para aqueles que as visualizam estabelecendo assim, através da apreciação de sua beleza, possíveis caminhos para estados subjetivos de percepção.

Presentes nas esculturas nos templos e fonte de inspiração para a literatura clássica e devocional da Índia, bem como para a criação de repertório da dança clássica indiana Odissi nos anos 50 do século XX, as alasa kanyas demonstram sua resiliência não somente por sua matéria-prima inicial, pedra resistente ao tempo, como atuam em literatura e aparições coreográficas. São renovadas em sua existência no universo contemporâneo e revelam-se ainda em diálogos, a princípio intraculturais, na própria Odisha que ansiava pelo reconhecimento de sua história dentro da Índia, e posteriormente interculturais e subjetivos, como na participação do videoclipe Black or White, ambas situações clamando por justiça, igualdade e liberdade identitária.

Batu, apelido de Batuka Bhairava, um dos nomes do deus da dança Shiva ${ }^{42}$, e que tudo transforma com o seu movimento cósmico e vigoroso, foi inspiração para os mestres que revitalizaram a dança Odissi e a ergueram como símbolo máximo de resistência artística de um povo tantas vezes subjugado por outros, impedindo o fluxo da arte, especialmente das mulheres, vítimas de preconceito e descaso, chegando à extinção completa da tradição mahari. Presente em vinte segundos do clipe do rei da dança pop do século XX, Michael Jackson, cujos giros e movimentos

42 Shiva Nataraja é considerado o deus da dança. Em suas outras formas, recebe outros nomes associados à diferentes funções. Shankara, Bathuka, Maheshwara são alguns de seus muitos epítetos. 
eróticos sempre em transformação, de si e do público espalhado pelo mundo, dança em duo, ao seu estilo, o mesmo Batu de Odisha, reinventado ao estilo pop.

Assim, tradição e criação contemporânea coexistem sem que uma macule a outra: nem a tradição se perde quando o intérprete acrescenta algo de si à obra, nem a criação contemporânea (igual à própria interpretação, que é atualizada a cada performance) se esvai do frescor que ela deve emanar para se caracterizar como arte e não como mera reprodução (Bonfitto, Andraus, 2014, p. 79).

Seja em dança pura ou expressiva, Black or White foi tomada pelas kanyas, ao surgirem quase imperceptíveis e fugazmente, porém cumprindo suas funções determinantes de contemplação ao trazerem visibilidade à rica tradição Odissi em uma obra contemporânea. Michael Jackson faz uma criação sobre a tradição em um videoclipe cuja arte, resiliente ao tempo e aos homens que a subjugam, tornase o próprio protesto como metalinguagem.

Quanto à discussão apresentada no início do artigo sobre a perspectiva intercultural, a despeito de alguns estereótipos presentes no videoclipe, o trecho em que foi convidada Yamuna Sangarasivam, uma artista que é profunda conhecedora da dança indiana Odissi, valoriza o videoclipe como um todo e tornao marcante para toda uma geração, abrindo perspectivas de pesquisa em dança para bailarinos do mundo inteiro e contribuindo para a discussão intercultural com uma potente e importante mensagem de equidade étnico-racial, de gênero e de justiça social.

\section{Referências}

AGAMBEN, Giorgio. O que é o contemporâneo? E outros ensaios. Tradução Vinícius Nicastro Honesko. Chapecó, SC: Argos, 2009.

ALBERGARIA, Andrea I. Mudras: os gestos da dança clássica indiana Odissi como caligrafia corporal na cena contemporânea. Curitiba: Editora CRV, 2020.

ASCHIERI, Patricia Cristina. Vínculos entre movimientos gesto y subjetividad: aportes socioantropológicos para pensar losentrenamientos em artes escénicas. Pós. Revista do Programa de Pós-Graduação em Artes da EBA/UFMG. V. 8, n. 16, nov. 2018. Disponível em <https://eba.ufmg.br/revistapos> 
ANDRADE, Joaquim. Shiva abandona seu trono: destradicionalização da dança hindu e sua difusão no Brasil. 2007. Tese (Doutorado em Ciências da Religião) Pontifícia Universidade Católica de São Paulo, São Paulo, 2007.

BHARUCHA, Rustom. Viajando através do interculturalismo: do pós-colonial ao presente global. OuvirOuver, Uberlândia, v. 13, n. 1, jan./jun., p. 12-23, 2017.

BONFITTO, M., ANDRAUS, M. B. M. A pregnância do vazio: a simbolização do gesto como espaço para a criação. In: SOARES, M. V., ANDRAUS, M. B. M., WILDHAGEN, J. (Orgs.). Mitos e símbolos na cena contemporânea: interlocuções oriente-ocidente. Jundiaí: Paco Editorial, 2014.

BURNETT, R., BERT, D. Black or white: Michael Jackson's video as a mirror of popular culture. Popular Music and Society. V. 19, 1995, Issue 3, p. 19-40. Disponível em: https://www.tandfonline.com/doi/abs/10.1080/03007769508591598

Acesso em: 25 maio 2021

CITARISTI, Ileana. The making of a guru - Kelucharan Mohapatra - his life and times New Delhi, Manohar, 2015.

COOTE, R 'Indian Classical Dance and the Temple of Konarak' TAASA Review: The Journal of the Asian Arts Society of Australia, v.4,n. 4, p. 16, 1995.

GONÇALVES, João. C.B. Celebração do mito no Gitagovinda de Jayadeva apresentação e tradução do poema sânscrito segundo sua relação com as narrativas épicas. 2004. Dissertação (Mestrado) - Faculdade de Filosofia, Letras e Ciências Humanas, Universidade de São Paulo, São Paulo, 2004.

DAVIS, Angela. Mulheres, raça e classe. Tradução de Heci Regina Candiani. São Paulo: Boitempo, 2016.

FANON, Frantz. Pele negra, máscaras brancas. São Paulo: Ubu Editora, 2020.

KLEFF, Michael. 1863: Estados Unidos abolem a escravidão. Disponível em: https://www.dw.com/pt-br/1863-estados-unidos-abolem-a-escravid\%C3\%A3o/a372001 Acesso em: 04 jun. 2021.

KRAMSRICH, Stella. Art of India - Traditions of Indian sculpture, painting and architecture - London: Phaidon Press, 1954.

LIGIÉRO, Zeca (org.). Performance e Antropologia de Richard Schechner. Rio de Janeiro: MAUAD, 2012.

MONTEN, Joshua. Algo velho, algo novo, algo emprestado: ecletismo na dança pósmoderna. Conceição/Conception, v. 4, n. 2, p. 111 - 128, 2015. Disponível em: https://periodicos.sbu.unicamp.br/ojs/index.php/conce/article/view/8647667/1454 6 Acesso em: 20 out. 2020

RABAKA, Reiland. The hip hop movement. from R\&B and the civil rights movement 
to rap and the hip hop generation. Washington DC: Lexington Books, 2013.

SAID, Edward W. Orientalismo: o Oriente como invenção do Ocidente. Trad. Rosaura Eichenberg. São Paulo: Companhia das Letras, 2007.

SANGARASIVAM, Yamuna. Disponível em: https://www2.naz.edu/dept/sociologyanthropology/faculty-and-staff/yamuna-sangarasivam/. Acesso em: 20 nov. 2020.

SARKAR, Kaustavi Mahari. Out. Desconstructing Odissi. Tese (Doutorado). Ohio State University, 2017.

SCHECHNER, Richard. A Reply to Rustom Bharucha. Asian Theatre Journal. V. 1, n. 2, Autumm, p. 245-253, 1984. Disponível em: https://www.jstor.org/stable/1124574. Acesso em: 12 nov. 2020.

SHARMAN, Surabhi. Secular Female Imagery in Orissan Temple Architecture: The Case of Alasa Kanyas. The Chitrolekha Journal on Art and Design, v. 4, n. 2, p. 1-10, 2020.

TANDON, Rekha. Classicism on the Threshold 'of Modernity. Expanding the Physical Parameters of Odissi Dance for Contemporary Audiences. Tese (Doutorado). Trinity Laban - London, UK, 2005.

VOGEL, Joseph. Man in the Music: The Creative Life and Work of Michael Jackson. New York, Sterling Publishing, 2011.

YOUTUBE. Michael Jackson - Black Or White (Official Video - Shortened Version). Disponível em: https://www.youtube.com/watch?v=F2AitTPI5U0. Acesso em: 13 nov. 2020

YOUTUBE. Michael Jackson rehearsing black or white 1991. Disponível em: https://youtu.be/RlEreLRqPHM Acesso em: 13 nov. 2020

Recebido em: 03/03/2021

Aprovado em: 07/06/2021 